\title{
Mediation Role of Revenue Management Practices on the Linkage between Hotel Determinants and Financial Performance of Hotels in Kenya
}

\author{
Michael Murimi'1, Billy Wadongo², Tom Olielo² \\ ${ }^{1}$ Department of Hotel \& Hospitality Management, Alupe University College, Alupe, Kenya \\ ${ }^{2}$ Department of Eco-Tourism, Hotels and Institutional Management, Maseno University, Maseno, Kenya \\ Email: mmurimi@auc.ac.ke, bwadongo@maseno.ac.ke, olielotom@gmail.com
}

How to cite this paper: Murimi, M., Wadongo, B., \& Olielo, T. (2021). Mediation Role of Revenue Management Practices on the Linkage between Hotel Determinants and Financial Performance of Hotels in Kenya. Open Journal of Business and Management, 9, 1805-1835.

https://doi.org/10.4236/ojbm.2021.94098

Received: June 16, 2021

Accepted: July 16, 2021

Published: July 19, 2021

Copyright $\odot 2021$ by author(s) and Scientific Research Publishing Inc. This work is licensed under the Creative Commons Attribution International License (CC BY 4.0).

http://creativecommons.org/licenses/by/4.0/

\begin{abstract}
The study aimed at investigating the mediation role of revenue management (RM) practices on the linkage between the internal and external hotel determinants and the financial performance of hotels in Kenya. The study used a quantitative approach adopted a cross-sectional survey research design. The study sampled 225 revenue managers from all-star-rated hotels in Kenya. Data were collected by use of a questionnaire. The findings revealed that, there was evidence of $\mathrm{RM}$ practice in hotels $(\mathrm{M}=2.44, \mathrm{SD}=0.671)$ and that the application of RM has some impacts on the financial performance of hotels $(M=3.35, S D=1.05)$. Further, the finding revealed a direct relationship between internal and external hotel determinants and financial performance of hotels $(\mathrm{R}=0.457$, Sig. $<0.05)$. And an indirect relationship between the internal and external hotel determinants and $R M$ practices $(R=0.478$, sig. $<$ $0.05)$, and further, $\mathrm{RM}$ practices and financial performance of hotels $(\mathrm{R}=$ 0.751 sig. $<0.05)$. The finding concluded that RM practices mediate the relationship between internal and external hotel determinants and financial performance $(\mathrm{R}=0.759$, sig. $<0.05)$. The beta value for internal and external hotel determinants that was initially (0.457) (in the direct relationship) reduced to $(0.127)$ after introducing RM practices as a vector mediator. The result shows that there is partial mediation, meaning that RM practices partially mediate the relationship between internal and external determinants and the financial performance of hotels. The findings recommend that hotels should enhance the adoption of RM practices to reduce the negative impacts of determinants and aim to contribute to hotels' financial performance. The research adds to the body of empirical evidence for revenue management and
\end{abstract}


financial performance conceptualization and description. The findings can aid in the conceptualization and advancement of future studies on hotel revenue management.

\section{Keywords}

External Determinants, Hotels, Internal Determinants, Revenue Management Practices, Kenya, Financial Performance

\section{Introduction}

The paper is organized under the following sub headings; background of the research, literature reviewed, methods used, findings and discussions, testing correlations, limitations, and conclusion.

\section{Background of the Research}

According to the World Travel \& Tourism Council's (WTTC) annual research on economic and social imports of the hotel sector, which has been in existence for the last 25 years, the global hotel sector, which is under the more significant tourism and travel sector, contributed $\$ 8.8$ trillion to the global economy in 2018. The hotel sector continues to be an essential engine of the Kenyan economy, as indicated by food services and accommodation's sustained contribution to GDP, which grew from $14.4 \%$ in 2017 to $16.6 \%$ in 2018 (Kenya National Bureau of Statistics, 2020).

Revenue management (RM) is a management method to increase sales revenues by altering the pricing at which frozen products such as hotel rooms are made available for sale based on current and expected demand (Hospitality Professionals Association, 2013). Revenue Management integration has been demonstrated to positively impact a hotel's financial performance and competitiveness, resulting in increased profitability for hotels and resorts (Ferguson \& Smith, 2014). Hotels can analyze their guests' preferences or booking habits, apply the optimal room prices, increase their business, and win against competition by implementing revenue management tactics (Patel, 2020). Revenue Management will use a consistent strategy to increase a hotel's real potential and maximize profitability (Abad, De la Fuente-Cabrero, González-Serrano, \& Talón-Ballestero, 2019). In the face of declining demand, hotels that employ a revenue management system (RMS) outperform non-RMS users; RMSs have proven more effective in increasing occupancy (Ortega, 2016). By managing room rates and reserving room allocations, revenue management maximizes a hotel's income and profitability. Its goal is to maximize revenue by using a flexible pricing policy to manage limited capacity, such as rooms.

According to the Tourism Regulatory Authority (TRA, 2020), the hotel industry comprises roughly 225 classed hotels ranging from one to five stars, with 
a total of 16,156 sellable rooms and 26,786 sellable beds. Since 2012 , the hotel business in Kenya has seen a decrease in room revenue between 2011 and 2015; Kenya's hotel business had a lower occupancy rate of 34.4 percent, compared to the Sub-Saharan African average of 59.4 percent, and European and American markets, which had occupancy rates of over 65.5 percent (Cytonn Real Estate, 2017). In addition, from 40.3 percent in 2011, 36.4 percent in 2012, 36.1 percent in 2013, 31.6 percent in 2014, and 29.1 percent in 2015 were recorded (Cytonn Real Estate, 2017; KNBS, 2020). In 2017 and 2018, there was a minor increase of 30 percent and 32.500 percent, respectively, before declining to 30.800 percent in 2019 (KNBS, 2020). Currently, there are around 16,156 sellable rooms with a total capacity of 26,786 beds, up 3\% from 2011 (TRA, 2020). Despite low hotel occupancy and very minimal growth over the years, the number of sellable hotel rooms in Kenya is increasing. During low peak seasons, occupancy rates might drop by as much as $80 \%$ (Miricho, 2013; Murimi \& Wadongo, 2021). Internal and external hotel factors will continue to harm Kenya's hotel business, depriving hotels of steady occupancies and opportunities to maximize hotel room rates and profits. Despite widespread promises and improvements in hotel revenue management methods, empirical research on $\mathrm{RM}$ techniques and their effects on Kenya's hotel business are lacking (Murimi, Wadongo, \& Olielo, 2021). Hotels are using revenue management tactics to manage low occupancy rates and improve income. By presenting empirical data and suggesting the mediation function of RM practices on the links between internal and external factors of RM practices and their implications on the financial performance of hotels in Kenya, the study aims to address gaps and expand current understanding.

\section{Literature Review}

\subsection{Revenue Management in Hotels}

Traditionally, revenue management has been characterized as the art and science of projecting demand while also modifying product pricing and availability to meet that need (López-Ruiz, Baeza-Gazca, Cantú-Flores, Webber-Garza, Arrambide-Leal, Ruiz-Cantisani, \& Cárdenas-Barrón, 2019). Initial hotel revenue management systems were modeled after airline revenue management systems, analyzing past data and estimating future booking patterns (Cross, Higbie, \& Cross, 2011). In addition, restaurants, spas, clubs, and entertainment parks have all begun to incorporate and execute RM strategies (Anderson \& Xie, 2010; Torc'h, 2015). By the year 2000, the great majority of hotel chains had begun to use RM systems extensively. Marriot, Hilton, Sheraton, Starwood, and InterContinental were among the first RM companies in the hotel business (Kimes, 2003). In today's hotel management, academia and the industry have agreed that competitive revenue management is a requirement for success (Noh, Lee, \& Lee, 2016). The development of increased revenues is linked to effective revenue management policies and implementation (Karmarkar \& Dutta, 2011). The current products or services and existing sets of consumers, clever pricing, and revenue 
management approaches have contributed billions of dollars to many organizations' bottom lines (Cross et al., 2011). When used correctly, revenue management systems (RM) have been shown to directly generate a $5 \%-10 \%$ increase in sales and improve occupancy rates during low points of the business cycle (Karmarkar \& Dutta, 2011; Morag, 2013). For example, using restaurant revenue management restaurants increased revenues from 3.5 percent to 7.3 percent (Bertsimas \& Popescu, 2003). The following sections of literature focus on internal and external determinants, RM practices and financial performance.

\subsection{Internal Hotel Determinants}

The impact of star ratings on revenue management is significant; nevertheless, it has little bearing on revenue management decision-making (Wang, Tian, $\mathrm{Li}$, \& Hu, 2013). Furthermore, Sainaghi (2011) discovered that star rating has a solid link to RevPAR. RM systems from a database of rated chain hotels are more effective at increasing occupancy than generating higher fees (Ortega, 2016). As a result, there is a strong link between hotel star rating and a few aspects of RM related to the financial performance of hotels.

The hotel is a location, and its set costs have long-term repercussions for the hotel's success (Baum \& Mezias, 1992). "The hotel industry frequently claims that the three most important factors in the success of restaurants and similar companies are location, location, and location (Baum \& Mezias, 1992: p. 585)." According to Sainaghi (2011), the hotel's central location increases its RevPAR approximate worth. In addition, Sainaghi (2011) investigated the "where" and "what" aspects with 72 respondents from 3 to 5-star hotels. According to financial surveys and summaries, the "what" is defined by four principles: the number of rooms, the number of staff, the time after the renovation, and the market orientation While ("where") emphasizes the importance of the location, particularly the hotel's location within the destination, market orientation emphasizes the relevance of the area. The location of the hotel has little bearing on Revenue Management policy or hotel performance (Wang et al., 2013). As a result, as mentioned above, hotel location has a substantial relationship with one aspect of RM performance. As a result, it is critical to determine whether there is a link between other components of RM procedures and hotel performance.

According to studies, the number of guest rooms and RevPAR has an inverse relationship (Sainaghi, 2011). In addition, the number of personnel in a hotel has a substantial impact on their productivity. Employees typically add value to occupancy or the worth of a property, resulting in a considerable impact on RevPAR (Sainaghi, 2011). The size of a hotel in terms of the number of rooms has a considerable impact on revenue management decisions. However, there is no connection with revenue management (Wang et al., 2013). Previous research has suggested that a company's size significantly impacts performance and scale efficiencies (Sainaghi, 2011).

Nonetheless, "size frequently captures not just the existence of economies of 
scale, but also the prevalence of diseconomies due to higher organization and management expenses" (Anastassopoulos, Filippaios, \& Phillips, 2009: p. 191). The total number of employees, rooms, and turnover is typically used to calculate a hotel's size. As a result, it is critical to see if the hotel's size has anything to do with RM practices or other aspects of its performance.

Dimensions of formation: Founding factors have a strong relationship with REVPAR. When new hotel upgrades need time to be noticed and provide positive results, time slack has a substantial impact on RevPAR (Sainaghi, 2011). As a result, it is critical to figure out if founding variables are linked to RM practices and other aspects of a hotel's financial performance.

Market orientation has an indirect association with RevPAR and "produces a degree of explained variance of 65 percent” (Jeffrey \& Barden, 2000a: p. 185). Furthermore, subsequent research employing comparable models (Jeffrey \& Barden, 2000b) confirmed the same results as the previous study (Sainaghi, 2011). As a result, it is important to see if market orientation is linked to RM practices and other financial performance indicators.

The room rates: To measure pricing by modifying hotel attributes and amenities, a hedonic price model was created and adopted. The residuals' spatial enquiries, on the other hand, may be able to deduce the rates of rooms not revealed by the model (Pawlicz \& Napierala, 2017). Furthermore, databanks of Online Travel Mediators and star assessments reveal that hotel star ratings have an effect on pricing, with each additional star rate authorizing a 25 - 36 percent impact on pricing. Hence, it is necessary to investigate if guest room rates are linked to RM practices.

\subsection{External Hotel Determinants}

Seasonality: These are time-based variations in the hotel industry; it is mainly measured by the number of clients, bookings, guest expenditures, mode of transportation, occupation entries, and web request traffic (Butler, 2001). Seasonality affects each hotel differently (Lee, Bergin-Seers, Galloway, O’Mahony, \& McMurray, 2008). Due to misshaped schemes that cause alternate ways of employing items in the hotel sector (Chiutsi \& Mudzengi, 2017); seasonality affects hotel performance (Chung, 2009). However, there is need to explore the relationship between seasonality and RM practices and hotel financial performance.

Changes in technology necessitate gathering and analyzing data for managers' use (Le Torc'h, 2015). Therefore, hotels should automate RM to improve organizational efficiency because it results in a 37.0 percent change (Kimes, 2010). Micros frameworks, mainly Fidelio package suite 8, are used by most hotels to manage their properties. This type of system encourages revenue management techniques such as dynamic pricing frameworks excited about occupancy rates. Revenue management is becoming more strategic, client-driven, and technologically focused, according to the papers, and will continue to be a crucial tool for hotel operations (Erdem, \& Jiang, 2016). As a result, it is essential to do empiri- 
cal research on technical advancements and their relationship to RM practices and hotel financial performance.

Guadix, Cortés, Onieva, and Muuzuri (2010) investigated new technology management and its significance in developing revenue management strategies; the findings demonstrated that technological advancement leads to more complex revenue business capabilities. Occupancy rate, efficiency rate, and yield were among the performance indicators examined. Occupancy rate, efficiency rate, and yield were among the performance indicators examined. Furthermore, by testing against actual data, the system improved its applicability for realworld scenarios, resulting in an effective and innovative solution for managing hotel booking systems.

Environmental Uncertainty: The extent of environmental uncertainty is the speed and rate at which an organization's state within the environment is changing (Awang, Ishak, Mohd-Radzi, \& Taha, 2008). The hotel industry is characterized by a long era of susceptibility, instability, economic unpredictability, political unpredictability, and fear-based oppression (Oaten, Le-Quesne, \& Segal, 2015). Several factors can explain the uncertainty in the hotel sector by combining six major measurements; Demand for guest rooms; changes in guest room rates; regulatory service changes; accessibility of labor and changes; changes in competitors' strategies; clients' likes and preferences (Awang et al., 2008).

Furthermore, prices charged by competitors, unpredictable changes in prices by suppliers, openings available for business capital and finance, demand curve, labor supply, market activities of new business competitors, and the effect of recent technology all add to the uncertainty in the hotel sector (Olsen, Tse, \& West, 1992). The rate of change in the environment has a substantial impact on the hotel's performance (Awang et al., 2008). While this is frequently the case, it is critical to determine whether uncertainty links to hotel RM practices' financial performance, which has not been effectively addressed.

Environmental complexity: this is the degree of variability within the organizational environment (Awang et al., 2008). Further, environmental complexity positively affects organizational performance because it regulates lean tasks and buying in organizations (Azadegan, Patel, Zangoueinezhad, \& Linderman, 2013). The complexity of the environment in the hotel sector may be measured using six indicators: the widespread convergence of competitors; the general grouping of sector sales; centralization of clients; services and product differentiation; centralization of labor accessibility; and Technological techniques within the business (Awang et al., 2008). While it is understandable that environmental complexity impacts companies' performance, this has not been satisfactorily investigated in the hotel sector here in Kenya (Njoroge et al., 2016). Hence, it is essential to determine if environmental complexity connected to RM practices \& the financial performance exists.

Environmental dynamism refers to the external business environment's volatility and unpredictability (Li \& Liu, 2014). Technological changes, market changes, 
clients, competition, competition unpredictability, change pace, and consumer behavior uncertainty are used to assess environmental dynamism (Wang, Senaratne, \& Rafiq, 2015). The rate at which a customer's preferences and a hotel's services vary over time is known as environmental dynamism (Wijbenga \& VanWitteloostuijn, 2007). Environmental dynamism has been shown to have a significant impact on organizational performance (Awang et al., 2008). The frequency and severity of the caused organizational changes are the two metrics for environmental dynamism (Mohd, Idris, \& Momani, 2013). Few studies have compared environmental dynamism to RM practices and hotel financial performance, so it is critical to figure out a link. Like JDA Software and Stay Night Automated Pricing (SNAP), new technology and revenue management tools are now being employed by hoteliers to increase income and stay ahead of the competition. Seasonality, an uncertain market, economic conditions, competition, and internal hotel drivers may obstruct the successful implementation of revenue management strategies.

Price-optimization; The pricing optimization aspect controls guest room rates based on occupancy, price variety, and modest prices, an approach utilized by more than 2000 InterContinental Group hotels (Koushik, Higbie, \& Eister, 2012). Furthermore, price optimization boosts revenue and employs a sophisticated advancement strategy that considers demand by many pieces as a separate entity from current revenue management structures (Koushik et al., 2012). One of the most critical concepts in today's valuation is dynamic pricing (Palmer \& McMahon-Beattie, 2008). Adding a price that reflects changes in demand and occupancy levels, hotels that use dynamic pricing can boost their returns and RevPAR (Tranter, Stuart-Hill, \& Parker, 2008). When considering bookings, customers regularly track different prices related to the room's number and status, as well as the length of time they are likely to remain (Palmer \& Mc-MahonBeattie, 2008; Tranter et al., 2008). Dynamic pricing provides additional benefits when used carefully in conjunction with relevant booking terms and conditions (Tranter et al., 2008).

Customers are supposed to be given price guarantees now and then (Demirciftci, Beldona, Cobanoglu, \& Cummings, 2010). Through a choice pricing framework, Carvell and Quan (2008) determined that, in order for consumers to benefit from these types of lowest price assurances, the guarantee should protect them from the time of booking until the time of arrival, which should not exceed 24 hours after making the booking. Liu (2012) created an optimizer tool for hotel booking to replace Cornell's standard price methodology for hotel booking. Because setting room rates are based on the desire to receive the room, the optimizer tool focused on the tool's requirement while selecting a room rate. Noone \& Mattila, (2009) compared and contrasted two price strategies, assorted and nonassorted, and their impact on customers' capacity to pay via online platforms. The non-assorted strategy generated more booking excitement than the mixed technique. 
Revenue forecasting: Revenue forecasting needs a decision-making process for tracking the business's performance. It investigates the effects of revenue forecasting by tracking business and decision-making performance with an indication in a highly complex industry and providing probability to other service sectors to comprehend and manufacture their gadgets (Whitfield \& Duffy, 2013).

Demand forecasting: Haensel \& Koole, (2011) study aimed at predicting the collective reservation curve and the number of bookings expected within the reservation horizon indicated a combined consideration of the connection and dynamic changes in reservations inside reservation booking frameworks. They also used a specific value breakdown to previous bookings and discovered fluctuations within the reservation horizon according to the forecast. When determining how the social media process adapts to RM, (Varini \& Sirsi, 2012) offered unique revenue-generating strategies. As internet-based processes become popular and investigators figure out how to execute them, hotels can opt to adopt all or some of them. They are more likely to succeed if they practice RM frequently (Noone, McGuire, \& Rohlfs, 2011).

Many web-based demonstrations, such as virtual networking, survey and review, and social networking, are primary locus attentions that hotels can adapt to when determining how to develop products, services, and pricing (Varini \& Sirsi, 2012). A study on meeting RM challenges: RM team knowledge, skills, and ability Knowledge, skills, and abilities, a two-step qualitative method developed by (Cetin, Demirciftci, \& Bilgihan, 2016) found that RM employees face a variety of complex issues, and they must be knowledgeable, possess applicable skills, and be capable of overcoming these obstacles. Cetin et al., (2016) used interviews and focus groups with eight participants to correct study data from 14 revenue managers and identify problems and capacities to increase revenue management effectiveness. RM ethical difficulties; even though RM techniques significantly impact hotel outcomes, there is much criticism of RM grievances and the absence of rational advantages required for pricing separation and overbooking procedures (Ivanov \& Zhechev, 2012).

In a study by (Noone, Enz, \& Glassmire, 2017), profits are more important in revenue management than mere income when variable expenditures and distribution are taken into account. Regardless of other hotel income and profit streams, such as spas, F \& B, and capacity space, extending revenue management to these centers creates complexity instead of its application in the room's sector. Extending RM practices to other sections will make for more accurate and necessary management in the for-profit sector. Total revenue management has grown in popularity in the hotel industry, and it is quickly becoming the next stage in revenue management's expansion. Hotels can achieve their revenue maximization goals in a competitive market by combining revenue streams from various hotel areas with income from rooms (Zheng \& Forgacs, 2017). It is critical to explore whether revenue collection automation, RM personnel knowledge, attitudes, abilities, and ethical issues impact hotel financial success. 


\subsection{Revenue Management Systems in Hotels}

The use of various RM methods and instruments by hotels to control the income they receive from clients is referred to as a revenue management system. Daily monitor activities, followed principal indicators, and client segmentation is four attention facts that aid revenue management in hotel RM systems (Wang, Yoonjoung Heo, Schwartz, Legohérel, \& Specklin, 2015). In a situation of decreasing interest, hotels with RM systems perform better than those without them, according to a study that employed a databank of 3 and above star-rated chain hotels and MANOVA and ANOVA analysis (Ortega, 2016).

In a pricing and capacity competition, the data suggested that RM systems are more effective at increasing occupancy than at reaching advanced rates and have no positive impact on employee productivity. Furthermore, revenue can be increased with RM systems, even if they are affected by changing market and economic conditions. Despite this, hotels have not embraced them because they do not significantly impact RevPAR (Ortega, 2016). Each night spent in a hotel room is treated as a separate asset in a revenue management network (Gallego \& Van-Ryzin, 1997). Great control strategies are created using the dynamic programming method (Zhang \& Weatherford, 2017). By managing visitor stays, deterministic linear generates up to 2.9 percent more predictable profits than traditional RM methods (Weatherford, 1995).

Data and information: Revenue forecasting necessitates inputs into a hotel RM system that is exceedingly complex, mainly information about customers (Morag, 2013). Historical data from archives is used when projecting bookings, managing occupancy, and maximizing revenue in hotels (Wang, Yoonjoung Heo, Schwartz, Legohérel, \& Specklin, 2015). RM system (Torc'h, 2015) is automated software that collects data on price rate, occupancy rate, and revenue from every room in a hotel for the previous years or seasons. There are four primary sources of RM data that can be used (Oliveri-Martínez-Pardo, 2017). There are four primary sources of RM data that can be used (Oliveri-MartínezPardo, 2017). These sources include hotels contacting competitors to inquire about rates; they utilize GDSs to calculate competitors' prices for various products and services and make pricing modifications. They may also use external data suppliers who regularly check reasonable competitors' websites to obtain the hotel's information. Online structures that provide their clients with useful approximate facts are also the reliable source (Oliveri-Martínez-Pardo, 2017).

RMS is globally recognized revenue management software programmed with strategic information useful to hotel managers (Torc'h, 2015). The software, however, comes at a considerable cost to hotels and requires expertise to implement it in their facilities. Through demand management and price optimization, the Carlson Rezidor Group of hotels has increased income. The organization employed JDA Software to boost income in various economic situations, estimating a $2 \%-4 \%$ rise in income and facing rivals in the hotel business (Pekgün, Menich, Acharya, Finch, Deschamps, Mallery, \& Fuller, 2013). Another well-estab- 
lished algorithm was able to anticipate revenue increases and decreases using hotel revenue records. The model could distinguish between short-term and long-term RM goals and assign shares accordingly (Padhi \& Aggarwal, 2011). Another integrated system for increasing room revenue was discovered; the system's framework included advancement and forecasting demand methods that handle clustered reservations with parameters such as reservations, no shows, seasonality, trends, and length of visitor stay (El Gayar, Saleh, Atiya, El-Shishiny, Zakhary, \& Habib, 2011).

RM Pricing devices: Pricing devices are commonly incorporated in RM, such as price discrimination, price guarantee, dynamic pricing, behavioral pricing, rate fences, and other tools that have an impact on the hotel's prices, though this is dependent on price rules, the hotel's structure, level, and presentation (Ivanov \& Zhechev, 2012). Price guarantee, price discrimination, and dynamic pricing are the most regularly used and researched RM pricing strategies in hotels (Choi \& Kimes, 2002; Ivanov \& Zhechev, 2012). Where dynamic pricing is used, hotel service providers may offer different rates. On the other hand, Prices are regarded as expensive if they irrationally exceed the standard or capacity of the services or products to which they are tied. As a result, each pricing should represent the advertised service or product (Anuwichanont, 2011). As a result, for pricing precision, hotels research by monitoring rivals' index ratings and ADR regularly to ensure that the prices are accurate and sustainable (Adedipe, 2018). Furthermore, several Kenyan hotels base their pricing policy on market figures published by the Kenya Tourism Board.

Hotels utilize price discrimination by charging varying prices for similar rooms to their customers. Differentials in prices targeting various market segments in the hospitality business could be linked to pricing discrimination. Customers on business trips, for example, are less sensitive to hotel rates than leisure customers since they can afford to pay higher prices (Ivanov \& Zhechev, 2012). In hotels, price fences are instances in which apparent goods and services are made available on the market. They include guest characteristics (for example, government representatives and club members), length of stay, payment terms, adjustments, cancellations, and the main duration (Kimes, 2010).

Price fences are designed to keep customers from taking advantage of low-cost services and products (Zhang \& Bell, 2010). As a result, when clients make a reservation, the price fence terms should be made clear. Non-pricing tools are linked to channel management and internal hotel processes such as overbookings, capacity management, controlled lengths of stay, and room availability assurance. Capacity management and overbookings are two very conventional revenue management non-pricing approaches (Talluri \& VanRyzin, 2006). In comparison to the controlled length of stay, which has gotten little attention in research, overbooking is a well-studied tactic (Ivanov \& Zhechev, 2012). To summarize, implementing RM systems has a significant impact on hotel performance (Ortega, 2016). However, it is critical to figure out whether the findings are context- 
specific or whether there are various reasons why hotels are not implementing RM models and systems.

\subsection{Hotel Financial Performance}

The actual occupancy performance of 3699 hotels that opened throughout the seven-year economic cycle of 2002 through 2008 was examined in a study by (O'Neill, 2011). The study looked at the length of time it took for a hotel to stabilize based on its kind, location, size, and degree of service. According to the findings, certain hotel types and locations stabilize more slowly or more quickly than others, whereas hotel size and service level are not significant drivers of the stabilization duration. According to a survey, the hotel industry believes it is sufficient to identify occupancy rate turning points or the moments when rising occupancy rates become falling occupancy rates and falling occupancy rates become rising occupancy rates (Tang, 2011).

From January 2005 to August 2014, Baldigara and Koic (2015) sought to evaluate and estimate the net occupancy rates of bed-places in the Croatian hotel business. For these goals, time-series forecasts were generated using the Naive seasonal model, the Holt-Winters exponential model, and the seasonal autoregressive integrated moving average model. According to the empirical findings, the time-series models used in this work performed well in MAPE, with the HoltWinters model beating both the seasonal nave and seasonal ARIMA models.

Mašić, (2013) investigated potential sources of efficiency in hotels by analyzing financial metrics. Operating revenue, revenue per room, room occupancy, investments, hotel prices, and payroll are unique indicators. The study covered a sample of around 31.35 percent of Serbia's total accessible hotel capacity from 2004 to 2011. From 2004 to 2011, a sample of around 31.35 percent of the total available hotel capacity in Serbia was used to determine the operating performance of hotel enterprises in Serbia. The sample was chosen to reflect the geographic and category distribution of hotels. Additionally, REVPAR and GOPPAR measurements were utilized to analyze hotel company business performance at the national level for tourism clusters and significant Serbian cities. According to the statistics, on average, hotel companies in Serbia have low REVPAR and GOPPAR values.

Santoro (2015) examined whether variables such as star rating, dimension, and added services provided correlate to occupancy performance. The findings revealed that each element has a varied impact on performance as evaluated by the RevPAR index. There is a strong relationship between performance and category (stars) (0.919). Furthermore, there is a strong link between hotel size and performance and between services supplied and performance, although the link between hotel size and performance is weaker (respectively 0.472 and 0.225 ). The quality looks to be critical for the hotel's performance improvement from a managerial standpoint. Customers perceive quality, but it is measured by allocating stars (category). 
Luo \& Lam (2017) used panel data from 1994 to 2014 to investigate the effects of urbanization on hotel performance and discovered that occupancy rate indicates hotel performance. As a result, the occupancy rate was a critical metric for assessing hotel performance. This research used a quantitative approach. As assessed by the economic, physical landscape, demographic, and social-cultural characteristics, the relationship between hotel performance and urbanization was investigated using statistical analysis. The findings indicate that urbanization has a significant impact on hotel performance. Future studies will be conducted using performance metrics such as ADR and ROI and macroeconomic factors that affect hotel profitability. In addition, local features (such as city size, intensity, and labor structure) may impact the hotel's performance. Finally, the study excludes some aspects that may influence hotel performance, such as policy and governance.

Shrestha \& Fissha, (2017) conducted qualitative research in Helsinki to see if Airbnb has an impact on hotel performance. They targeted hostels to five-star hotels. The study sought to determine whether the presence of Airbnb has any effect on hotels and whether hotels compete with Airbnb. Has the presence of a competitor affected the hotel's occupancy rate, price, or revenue? The data revealed that hotel performance has continued to improve while an increasing number of hosts are renting out their homes on Airbnb. Hotel rooms have been effectively sold, with overnight stays, occupancy rates, and RevPAR all increasing. Overall, Airbnb is not seen as a danger to the hotel industry in Helsinki because it has no negative impact on its performance.

The above reviewed studies have found that many factors influence hotel financial performance. Revenue per room, occupancy, operating revenue, investments, room rates, payroll, and dominant seasonality, volatility, and industry unpredictability are only a few of them. In addition, hotels that had made significant expenditures saw significant improvements in financial performance, such as hotels constructed in manufacturing areas. The findings also show that models built for hotel performance performed well in different seasons, such as winter or the nave. Further, urbanization has an impact on hotel performance. As a result, future research should measure hotel financial performance using ADR, ROI, and measures. Unfortunately, few comparable studies have been conducted in the Kenyan hotel industry. This research aimed at evaluating the financial performance metrics of hotels in Kenya.

\section{Methodology}

A cross-sectional survey design was used in this investigation. This research focused on Kenya's star-rated categorized hotels and facilities. The star rating system runs from one to five stars, with facilities located throughout Kenya in various locations. These hotel clusters are well-established and dominate a wide range of market segments. The star-rated hotels were singled out for their extensive standard operating procedures. 
Furthermore, when compared to non-classified hotels, RM techniques have a more significant number of application possibilities in classified hotels. The scale of operations in star-rated facilities allows them to take such practices, which are regarded to be more affluent in non-classified hotels (Murimi \& Wadongo, 2021; Odawa, 2017). The units of study in this study were Kenya's 225 star-rated hotels (TRA, 2020). There are 25 five-star hotels, 71 four-star hotels, 66 three-star hotels, 62 two-star hotels, and three one-star hotels in the gazetted star-rated facilities cluster. There were just a few one-star hotels in the cluster, but many unclassified establishments took pride in being part of it.

Revenue managers and accounting managers were among those who responded. The responders play a crucial role in the hotel's revenue management operations and are hence experts in their field. Each star-rated hotel had one (1) respondent, resulting in 225 total respondents for the survey. Data were collected from respondents via a questionnaire. The literature review for the questionnaire was modified from the RM theoretical framework's literature review (Murimi et al., 2021). Furthermore, the researchers borrowed some elements from prior research to assess the variables better; for example, several questions on revenue management methods were borrowed from (Miricho, 2013) and modified by the researcher; (Murimi \& Wadongo, 2021).

\subsection{Findings on Internal Hotel Determinants}

The study achieved a usable response rate of $60.89 \%$. About $31.4 \%$ were responses from three-star-rated facilities, followed by $28.5 \%$ from four-star-rated at and $27 \%$ from two star-rated; only $12.4 \%$ and $0.7 \%$ for five-star-rated and one star-rated facility respectively. About $78.1 \%$ of these hotels were found in urban areas, while $11.7 \%$ were in the semi-urban region and $10.2 \%$ are in rural areas. Further, findings reveal that $77.4 \%$ of these star-rated facilities are independent while only $22.6 \%$ are chain affiliated. In terms of establishment, only $9.5 \%$ of hotels that responded were less than five years old, while $15.3 \%$ were over 21 . The rest of the star-rated hotels have been in operations over 6 - 20 years. Findings indicated that most of the hotels, $75.2 \%$ indicated to have done refurbishment less than five years ago. While $15.3 \%$ did refurbishment 1 - 10 years and 0nly $9.5 \%$ did it 11 - 15 years ago-none of the hotels registered to not have done refurbishment for periods longer than that since establishment. The responses indicate that many hotels have between 1 to 100 rooms, with $36.5 \%$ with less than 50 rooms and $37.2 \%$ with between 50 - 100 rooms. The hotels with over 300 rooms are very few, just $1.5 \%$. Other categories, $101-150$ rooms are about $8.8 \%, 151$ - 200 rooms are about 8.0\%, $201-250$ about $5.1 \%$ while $251-300$ rooms about $2.9 \%$. The room prices show that most hotels, $37.2 \%$, and $19.0 \%$, agree and strongly agree that they are fixed until the next review. In contrast, about a total of $10.9 \%$ disagree.

Further, Table 1 on room prices and customer orientation reveals a high mean of above 3/5. For instance, hotels experience high and low season. Above 
Table 1. On room prices and customer orientation.

\begin{tabular}{|c|c|c|c|c|c|c|c|c|}
\hline \multirow{2}{*}{$\begin{array}{l}\text { Room prices \& Customer } \\
\text { orientation }\end{array}$} & \multirow{2}{*}{$\begin{array}{c}\mathrm{N} \\
\text { Statistic }\end{array}$} & \multicolumn{5}{|c|}{ Frequency in Percentages } & \multirow{2}{*}{$\begin{array}{c}\text { Mean } \\
\text { Statistic }\end{array}$} & \multirow{2}{*}{$\begin{array}{c}\begin{array}{c}\text { Std. } \\
\text { Deviation }\end{array} \\
\text { Statistic }\end{array}$} \\
\hline & & $\begin{array}{l}\text { Strongly } \\
\text { Disagree }\end{array}$ & Disagree & Average & Agree & $\begin{array}{l}\text { Strongly } \\
\text { agree }\end{array}$ & & \\
\hline Room prices are fixed until the next reviews. & 137 & $2.2 \%$ & $8.8 \%$ & $32.8 \%$ & $37.2 \%$ & $19.0 \%$ & 3.62 & 0.964 \\
\hline Hotel has low season and high season prices. & 137 & $0 \%$ & $7.3 \%$ & $22.6 \%$ & $38.7 \%$ & $31.4 \%$ & 3.94 & 0.914 \\
\hline Hotel uses local and foreign visitor prices. & 137 & $5.1 \%$ & $19.7 \%$ & $17.5 \%$ & $23.4 \%$ & $34.3 \%$ & 3.62 & 1.278 \\
\hline Room prices vary according to the market being quoted. & 137 & $0.7 \%$ & $23.4 \%$ & $43.8 \%$ & $23.4 \%$ & $8.8 \%$ & 3.16 & 0.909 \\
\hline $\begin{array}{l}\text { Room prices are fixed with different discounts } \\
\text { to different identified market segments. }\end{array}$ & 137 & $1.5 \%$ & $24.8 \%$ & $38.0 \%$ & $25.5 \%$ & $10.2 \%$ & 3.18 & 0.972 \\
\hline When occupancy is low this hotel lowers the prices & 137 & $0 \%$ & $11.7 \%$ & $26.3 \%$ & $16.8 \%$ & $45.3 \%$ & 3.96 & 1.091 \\
\hline Market orientation for this hotel is customer oriented & 137 & $0 \%$ & $5.8 \%$ & $36.5 \%$ & $38.0 \%$ & $19.7 \%$ & 3.72 & 0.848 \\
\hline Hotel caters to the wants and needs of its clientele & 137 & $0 \%$ & $0 \%$ & $18.2 \%$ & $65.0 \%$ & $6.8 \%$ & 3.99 & 0.594 \\
\hline $\begin{array}{l}\text { Hotel practices the following; information gathering } \\
\text { and dissemination, and a quick response to current } \\
\text { and future customer needs and preferences }\end{array}$ & 137 & $0 \%$ & $2.2 \%$ & $29.9 \%$ & $51.1 \%$ & $16.8 \%$ & 3.82 & 0.727 \\
\hline Valid N (listwise) & 137 & & & & & & & \\
\hline
\end{tabular}

Source: Authors computation, (2021).

$50 \%$ of hotels have both local and foreign prices for their guests. It is attributed to the nature of services, and the clientele target market is global. Most of the hotels have fixed prices till the following review, and they vary according to the market quoted. The rooms are fixed with different discounts to different identified market segments. When occupancy is low, the hotels lower their prices. The hotel's orientation is towards clients and meeting their needs. There is a practice of information gathering and quick disseminating information to the customers to meet their preferences.

\subsection{Findings on External Hotel Determinants}

Table 2 shows means for seasonality changes and technological changes have and how they have affected hotels. Changes in seasonality were also found to affect hotels. Hotel experiences low and peak seasons $(M=3.99, S D=0.907)$. Also hotels were not affected by seasonal fluctuation of clients $(M=4.18, S D=0.815)$. Further results reveal that hotels can be able to predict seasonal fluctuations (M $=3.90, \mathrm{SD}=0.789)$. Overall results reveal that seasonal fluctuations highly affect hotel bookings and or reservations $(\mathrm{M}=3.33, \mathrm{SD}=1.362)$. The results of technological changes shows that hotels have adopted technological innovations in their operations $(\mathrm{M}=4.31, \mathrm{SD}=2.66)$ and these innovations have improved operations $(M=3.97, S D=0.757)$. Technological innovations are important in gathering information $(\mathrm{M}=3.83, \mathrm{SD}=0.854)$, trailing prices $(\mathrm{M}=3.82, \mathrm{SD}=$ $0.842)$, forecasting $(M=3.82, S D=0.901)$ and have increased hotel efficiency $(M$ $=3.88, \mathrm{SD}=1.025)$. 
Table 2. Seasonality and technological changes.

\begin{tabular}{|c|c|c|c|c|c|c|c|c|}
\hline \multirow[t]{2}{*}{ seasonality changes } & \multirow{2}{*}{$\begin{array}{c}\mathrm{N} \\
\text { Statistic }\end{array}$} & \multirow[t]{2}{*}{$\begin{array}{l}\text { Strongly } \\
\text { Disagree }\end{array}$} & \multirow[t]{2}{*}{ Disagree } & \multirow[t]{2}{*}{ Average } & \multirow[t]{2}{*}{ Agree } & \multirow[t]{2}{*}{$\begin{array}{l}\text { Strongly } \\
\text { Agree }\end{array}$} & \multirow{2}{*}{$\begin{array}{c}\text { Mean } \\
\text { Statistic }\end{array}$} & \multirow{2}{*}{$\begin{array}{c}\begin{array}{c}\text { Std. } \\
\text { Deviation }\end{array} \\
\text { Statistic }\end{array}$} \\
\hline & & & & & & & & \\
\hline Hotel experiences low and peak customer seasons & 137 & $0 \%$ & $4.4 \%$ & $28.5 \%$ & $31.4 \%$ & $35.8 \%$ & 3.99 & 0.907 \\
\hline $\begin{array}{l}\text { Hotel is not affected by seasonal } \\
\text { fluctuations of clients }\end{array}$ & 137 & $0 \%$ & $0.7 \%$ & $23.4 \%$ & $32.8 \%$ & $43.1 \%$ & 4.18 & 0.815 \\
\hline $\begin{array}{l}\text { Hotel can be able to predict } \\
\text { seasonal fluctuations }\end{array}$ & 137 & $0 \%$ & $3.6 \%$ & $25.5 \%$ & $48.2 \%$ & $22.6 \%$ & 3.90 & 0.789 \\
\hline $\begin{array}{l}\text { Seasonal fluctuations of clients affects } \\
\text { bookings/reservations of this hotel heavily }\end{array}$ & 137 & $10.9 \%$ & $19.7 \%$ & $23.4 \%$ & $17.5 \%$ & $28.5 \%$ & 3.33 & 1.362 \\
\hline \multicolumn{9}{|c|}{ Technological changes } \\
\hline $\begin{array}{l}\text { Hotel has adopted technological innovations in } \\
\text { its operations }\end{array}$ & 137 & $0 \%$ & $0 \%$ & $21.9 \%$ & $46.0 \%$ & $32.1 \%$ & 4.31 & 2.656 \\
\hline $\begin{array}{l}\text { Technological changes have improved } \\
\text { operations in this hotel }\end{array}$ & 137 & $0 \%$ & $2.9 \%$ & $21.2 \%$ & $51.8 \%$ & $24.1 \%$ & 3.97 & 0.757 \\
\hline $\begin{array}{l}\text { Technological innovations adopted are } \\
\text { vital in gathering information }\end{array}$ & 137 & $1.5 \%$ & $4.4 \%$ & $24.1 \%$ & $49.6 \%$ & $20.4 \%$ & 3.83 & 0.854 \\
\hline The innovations are used in trailing prices & 137 & $0 \%$ & $5.1 \%$ & $30.7 \%$ & $41.6 \%$ & $22.6 \%$ & 3.82 & 0.842 \\
\hline The innovations are used in forecasting & 137 & $0.7 \%$ & $8.0 \%$ & $22.6 \%$ & $46.0 \%$ & $22.6 \%$ & 3.82 & 0.901 \\
\hline $\begin{array}{l}\text { Technological changes have increased } \\
\text { hotel efficiency }\end{array}$ & 137 & $2.2 \%$ & $7.3 \%$ & $24.1 \%$ & $33.6 \%$ & $32.8 \%$ & 3.88 & 1.025 \\
\hline Valid N (listwise) & 137 & & & & & & & \\
\hline
\end{tabular}

Source: Authors computation, (2021).

The findings on Table 3 revealed that environmental complexity factors heavily affected operations in hotels. The factors under consideration in this category are concentration of competitors within the business location $(\mathrm{M}=2.75, \mathrm{SD}=$ $0.511)$, geographic concentration of target customers $(M=2.75, S D=0.543)$. Availability of labor $(\mathrm{M}=2.39, \mathrm{SD}=0.546)$, variety of products and or services $(\mathrm{M}=2.60, \mathrm{SD}=0.562)$ Geographic location of hotel $(\mathrm{M}=2.80, \mathrm{SD}=0.456)$. Further, uncertainty factors found to likely affect operations hotel includes changes in guest room rates $(\mathrm{M}=2.48, \mathrm{SD}=0.583)$ changes in labor availability $(\mathrm{M}=2.14, \mathrm{SD}=0.583)$, changes in demand for guest rooms $(\mathrm{M}=2.88, \mathrm{SD}=$ $0.373)$, changes in competitive tactics used by competitors $(\mathrm{M}=2.55, \mathrm{SD}=$ $0.605)$. Changes in regulatory service and activities $(M=2.35, S D=0.589)$, changes in customer service and preferences $(\mathrm{M}=2.47, \mathrm{SD}=0.569)$ oppression by fears of pandemic and market structures $(\mathrm{M}=2.35, \mathrm{SD}=0.589)$.

Table 4 shows findings on general environmental dynamisms that were found to affect hotel operations in a big way regulatory environment $(M=5.03, \mathrm{SD}=$ $0.962)$, social economic environment $(\mathrm{M}=4.74, \mathrm{SD}=0.932)$ political and security aspects $(M=4.64, S D=0.999)$ and technological environment $(M=4.97$, $\mathrm{SD}=1.014)$. 
Table 3. Environmental complexity and uncertainty factors.

\begin{tabular}{|c|c|c|c|c|c|c|}
\hline \multirow[t]{2}{*}{ Environmental complexity factors } & $\mathbf{N}$ & \multirow[t]{2}{*}{ Lowly } & \multirow[t]{2}{*}{ Moderately } & \multirow[t]{2}{*}{ Highly } & \multirow{2}{*}{$\begin{array}{c}\text { Mean } \\
\text { Statistic }\end{array}$} & \multirow{2}{*}{$\begin{array}{c}\begin{array}{c}\text { Std. } \\
\text { Deviation }\end{array} \\
\text { Statistic }\end{array}$} \\
\hline & Statistic & & & & & \\
\hline Concentration of competitors within this location & 137 & $3.6 \%$ & $17.5 \%$ & $78.8 \%$ & 2.75 & 0.511 \\
\hline Geographic concentration of target customers. & 137 & $2.2 \%$ & $48.2 \%$ & $49.6 \%$ & 2.47 & 0.543 \\
\hline Labor availability & 137 & $2.9 \%$ & $55.5 \%$ & $41.6 \%$ & 2.39 & 0.546 \\
\hline Variety of products/services provided by the hotel & 137 & $3.6 \%$ & $32.8 \%$ & $63.5 \%$ & 2.60 & 0.562 \\
\hline Geographic location of the hotel & 137 & $2.2 \%$ & $16.1 \%$ & $81.8 \%$ & 2.80 & 0.456 \\
\hline \multicolumn{7}{|l|}{ Uncertainty factors } \\
\hline Changes in guest room rates & 137 & $4.4 \%$ & $43.1 \%$ & $52.6 \%$ & 2.48 & 0.583 \\
\hline Changes in labor availability & 137 & $24.1 \%$ & $38.0 \%$ & $38.0 \%$ & 2.14 & 0.778 \\
\hline Changes in demand for guest rooms & 137 & $1.5 \%$ & $9.5 \%$ & $89.1 \%$ & 2.88 & 0.373 \\
\hline Changes in competitive tactics used by competitors & 137 & $5.8 \%$ & $32.8 \%$ & $61.3 \%$ & 2.55 & 0.605 \\
\hline Changes in regulatory service and activities & 137 & $5.8 \%$ & $53.3 \%$ & $40.9 \%$ & 2.35 & 0.589 \\
\hline Changes in customers' tastes and preferences & 137 & $3.6 \%$ & $46.0 \%$ & $50.4 \%$ & 2.47 & 0.569 \\
\hline Oppression by fears and Pandemics & 137 & $0 \%$ & $20.4 \%$ & $79.6 \%$ & 2.80 & 0.405 \\
\hline Changes in market structures & 137 & $2.9 \%$ & $10.9 \%$ & $86.1 \%$ & 2.83 & 0.447 \\
\hline Valid N (listwise) & 137 & & & & & \\
\hline
\end{tabular}

Source: Authors computation, (2021).

Table 4. On General environmental dynamisms.

\begin{tabular}{|c|c|c|c|c|c|c|c|c|}
\hline \multirow{2}{*}{$\begin{array}{l}\text { General environmental } \\
\text { dynamisms }\end{array}$} & $\mathbf{N}$ & \multirow[t]{2}{*}{$\begin{array}{l}\text { Very } \\
\text { rarely }\end{array}$} & \multirow[t]{2}{*}{ Rarely } & \multirow[t]{2}{*}{ Occasionally } & \multirow[t]{2}{*}{ Frequently } & \multirow[t]{2}{*}{$\begin{array}{l}\text { Very } \\
\text { Frequently }\end{array}$} & \multirow{2}{*}{$\begin{array}{c}\text { Mean } \\
\text { Statistic }\end{array}$} & \multirow{2}{*}{$\begin{array}{c}\text { Std. } \\
\text { Deviation } \\
\text { Statistic }\end{array}$} \\
\hline & Statistic & & & & & & & \\
\hline $\begin{array}{l}\text { Regulatory environment } \\
\text { (e.g. laws, regulations, policies) }\end{array}$ & 137 & $0 \%$ & $8.0 \%$ & $20.4 \%$ & $32.1 \%$ & $39.4 \%$ & 5.03 & 0.962 \\
\hline $\begin{array}{l}\text { Social economic environment } \\
\text { (e.g. inflation, population, crime, disasters) }\end{array}$ & 137 & $0 \%$ & $8.0 \%$ & $35.0 \%$ & $31.4 \%$ & $25.5 \%$ & 4.74 & 0.932 \\
\hline $\begin{array}{c}\text { Political and security aspects } \\
\text { (e.g. elected leaders, politics, violence) }\end{array}$ & 137 & $0 \%$ & $12.4 \%$ & $37.2 \%$ & $24.8 \%$ & $25.5 \%$ & 4.64 & 0.999 \\
\hline $\begin{array}{l}\text { Technological environment } \\
\text { (e.g. innovations, ICT) }\end{array}$ & 137 & $0 \%$ & $8.8 \%$ & $26.3 \% \%$ & $24.1 \%$ & $40.9 \%$ & 4.97 & 1.014 \\
\hline
\end{tabular}

Source: Authors computation, (2021).

\subsection{Application of Revenue Management Practices}

Table 5 present findings on RM policies and implementation revealed that hotels apply revenue management policies $(\mathrm{M}=2.45, \mathrm{SD}=0.985)$. There are individuals in charge of $\mathrm{RM}$ policy implementation $(\mathrm{M}=3.47, \mathrm{SD}=0.993)$. The hotels induct new employees on $\mathrm{Rm}$ policies $(\mathrm{M}=3.45, \mathrm{SD}=0.999)$. $\mathrm{RM}$ policies 
Table 5. RM policies and implementation.

\begin{tabular}{|c|c|c|c|c|c|c|c|c|}
\hline \multirow[t]{2}{*}{ RM Policies \& Implementation } & \multirow{2}{*}{$\begin{array}{c}\mathrm{N} \\
\text { Statistic }\end{array}$} & \multirow{2}{*}{$\begin{array}{l}\text { Strongly } \\
\text { Disagree }\end{array}$} & \multirow[t]{2}{*}{ Disagree } & \multirow[t]{2}{*}{ Average } & \multirow[t]{2}{*}{ Agree } & \multirow{2}{*}{$\begin{array}{l}\text { Strongly } \\
\text { Agree }\end{array}$} & \multirow{2}{*}{$\begin{array}{c}\text { Mean } \\
\text { Statistic }\end{array}$} & \multirow{2}{*}{$\begin{array}{c}\begin{array}{c}\text { Std. } \\
\text { Deviation }\end{array} \\
\text { Statistic }\end{array}$} \\
\hline & & & & & & & & \\
\hline Application of revenue management policies & 137 & $07 \%$ & $18.2 \%$ & $32.1 \%$ & $33.6 \%$ & $15.3 \%$ & 3.45 & 0.985 \\
\hline $\begin{array}{c}\text { Somebody in charge of revenue management } \\
\text { implementation }\end{array}$ & 137 & $2.9 \%$ & $12.4 \%$ & $34.3 \%$ & $35.6 \%$ & $15.3 \%$ & 3.47 & 0.993 \\
\hline Induction of new employees on RM policies & 137 & $1.5 \%$ & $16.8 \%$ & $33.6 \%$ & $32.1 \%$ & $16.1 \%$ & 3.45 & 0.999 \\
\hline $\mathrm{RM}$ policies is used making decisions & 137 & $3.6 \%$ & $7.3 \%$ & $33.6 \%$ & $43.1 \%$ & $12.4 \%$ & 3.53 & 0.932 \\
\hline $\begin{array}{l}\text { Revenue managers oversee implementation } \\
\text { of RM policies }\end{array}$ & 137 & $1.5 \%$ & $19.0 \%$ & $27.0 \%$ & $39.4 \%$ & $13.1 \%$ & 3.44 & 0.992 \\
\hline $\begin{array}{l}\text { The management support implementation } \\
\text { of RM policies to the core. }\end{array}$ & 137 & $2.2 \%$ & $12.4 \%$ & $32.8 \%$ & $29.2 \%$ & $23.4 \%$ & 3.59 & 1.047 \\
\hline $\begin{array}{l}\text { RM policies help manage the finances } \\
\text { of this hotel }\end{array}$ & 137 & $2.2 \%$ & $13.9 \%$ & $25.5 \%$ & $34.3 \%$ & $24.1 \%$ & 3.64 & 1.062 \\
\hline Valid N (listwise) & 137 & & & & & & & \\
\hline
\end{tabular}

Source: Authors computation, (2021).

are regularly used when making decisions in hotels $(\mathrm{M}=3.53, \mathrm{SD}=0.932)$. Revenue managers are tasked to oversee the implementation of RM policies ( $M$ $=3.44, \mathrm{SD}=0.992)$. Management of various hotels supports the implementation of $\mathrm{RM}(\mathrm{M}=3.59, \mathrm{SD}=1.047)$. $\mathrm{RM}$ policies have assisted hotels in managing the finances of this hotel $(\mathrm{M}=3.64, \mathrm{SD}=1.062)$. The findings support the affirmations that implementing innovative RM and reservation policies may help hoteliers increase income (Enz et al., 2010; Hernandez, 2015).

Table 6 presents findings on RM techniques that reveal that commonly used in star-rated hotels include price optimization tools $(\mathrm{M}=4.39, \mathrm{SD}=0.965)$. $\mathrm{Dy}$ namic pricing tool $(\mathrm{M}=4.46, \mathrm{SD}=0.891)$, revenue forecasting $(\mathrm{M}=4.35, \mathrm{SD}=$ $0.801)$, and demand forecasting $(\mathrm{M}=4.69, \mathrm{SD}=1.027)$. The use of these tools affirms their importance in hotels as it is a valuable strategy being used nowadays (Palmer \& Mc-Mahon-Beattie, 2008) and they used by more than $2000 \mathrm{In}$ terContinental Group of hotels (Koushik, et al., 2012).

Table 7 with findings on the revenue management team, shows that the team was knowledgeable and skilled $(\mathrm{M}=3.85, \mathrm{SD}=1.007)$, the team has the right attitude for the job $(\mathrm{M}=3.79, \mathrm{SD}=0.950)$. $\mathrm{RM}$ is capable of handling $\mathrm{RM}$ challenges $(\mathrm{M}=3.69, \mathrm{SD}=0.904) . \mathrm{RM}$ team is a team of Integrity $(\mathrm{M}=$ $3.88, \mathrm{SD}=0.835)$. There are rare cases of $\mathrm{RM}$ unethical issues $(\mathrm{M}=3.96, \mathrm{SD}=$ 0.966). To achieve the purpose of RM (Cetin et al., 2016), revealed that RM staff experience is full of sophisticated difficulties and they should be knowledgeable, have relevant skills and capabilities to allow them to overcome these challenges.

Table 8 on Integration of social media in RM findings reveal that hotels have integrated social media in $R M$ activities $(M=4.26, S D=0.993)$, the social 
Table 6. RM techniques.

\begin{tabular}{|c|c|c|c|c|c|c|c|c|}
\hline \multirow[t]{2}{*}{ RM techniques } & $\mathbf{N}$ & Very & Rarely & Occasionally & Frequently & \multirow{2}{*}{$\begin{array}{c}\text { Very } \\
\text { Frequently }\end{array}$} & Mean & \multirow{2}{*}{$\begin{array}{c}\text { Std. } \\
\text { Deviation }\end{array}$} \\
\hline & Statistic & & & & & & Statistic & \\
\hline Price optimization tool & 137 & $0 \%$ & $8.0 \%$ & $20.4 \%$ & $32.1 \%$ & $39.4 \%$ & 4.39 & 0.965 \\
\hline Dynamic pricing tool & 137 & $0 \%$ & $8.0 \%$ & $35.0 \%$ & $31.4 \%$ & $25.5 \%$ & 4.46 & 0.891 \\
\hline Revenue forecasting & 137 & $0 \%$ & $12.4 \%$ & $37.2 \%$ & $24.8 \%$ & $25.5 \%$ & 4.35 & 0.801 \\
\hline Demand forecasting & 137 & $0 \%$ & $8.8 \%$ & $26.3 \% \%$ & $24.1 \%$ & $40.9 \%$ & 4.69 & 1.027 \\
\hline Valid N (listwise) & 137 & & & & & & & \\
\hline
\end{tabular}

Source: Authors computation, (2021).

Table 7. RM team.

\begin{tabular}{|c|c|c|c|c|c|c|c|c|}
\hline \multirow[t]{2}{*}{$\mathrm{RM}$ team } & \multirow{2}{*}{$\begin{array}{c}\mathrm{N} \\
\text { Statistic }\end{array}$} & \multirow{2}{*}{$\begin{array}{l}\text { Strongly } \\
\text { Disagree }\end{array}$} & \multirow[t]{2}{*}{ Disagree } & \multirow[t]{2}{*}{ Average } & \multirow[t]{2}{*}{ Agree } & \multirow{2}{*}{$\begin{array}{l}\text { Strongly } \\
\text { Agree }\end{array}$} & \multirow{2}{*}{$\begin{array}{c}\text { Mean } \\
\text { Statistic }\end{array}$} & \multirow{2}{*}{$\begin{array}{c}\begin{array}{c}\text { Std. } \\
\text { Deviation }\end{array} \\
\text { Statistic }\end{array}$} \\
\hline & & & & & & & & \\
\hline RM team is knowledgeable and skilled & 137 & $0.7 \%$ & $8 \%$ & $30.7 \%$ & $27.0 \%$ & $37.0 \%$ & 3.85 & 1.007 \\
\hline $\begin{array}{l}\text { RM employees have the right attitude } \\
\text { for their Job. }\end{array}$ & 137 & $0 \%$ & $9.5 \%$ & $29.2 \%$ & $34.3 \%$ & $27.0 \%$ & 3.79 & 0.950 \\
\hline $\begin{array}{c}\text { RM team is capable of handling } \\
\text { RM challenges }\end{array}$ & 137 & $0 \%$ & $8.8 \%$ & $34.5 \%$ & $35.3 \%$ & $21.2 \%$ & 3.69 & 0.904 \\
\hline $\mathrm{RM}$ team is a team of integrity & 137 & $0 \%$ & $4.4 \%$ & $28.5 \%$ & $42.3 \%$ & $24.8 \%$ & 3.88 & 0.835 \\
\hline We rarely handle RM unethical issues & 137 & $0 \%$ & $7.3 \%$ & $25.5 \%$ & $31.4 \%$ & $35.7 \%$ & 3.96 & 0.966 \\
\hline Valid N (listwise) & 137 & & & & & & & \\
\hline
\end{tabular}

Source: Authors computation, (2021).

Table 8. Integration of social media in RM.

\begin{tabular}{|c|c|c|c|c|c|c|c|c|}
\hline \multirow{2}{*}{$\begin{array}{l}\text { Social media } \\
\text { integration } \\
\text { with RM }\end{array}$} & \multirow{2}{*}{$\begin{array}{c}\text { N } \\
\text { Statistic }\end{array}$} & \multirow{2}{*}{$\begin{array}{l}\text { Very } \\
\text { Rarely }\end{array}$} & \multirow[t]{2}{*}{ Rarely } & \multirow[t]{2}{*}{ Occasionally } & \multirow[t]{2}{*}{ Frequently } & \multirow{2}{*}{$\begin{array}{l}\text { Very } \\
\text { Frequently }\end{array}$} & \multirow{2}{*}{$\begin{array}{c}\text { Mean } \\
\text { Statistic }\end{array}$} & \multirow{2}{*}{$\begin{array}{c}\begin{array}{c}\text { Std. } \\
\text { Deviation }\end{array} \\
\text { Statistic }\end{array}$} \\
\hline & & & & & & & & \\
\hline Social media integration on RM activities & 137 & $2.9 \%$ & $18.2 \%$ & $41.6 \%$ & $24.8 \%$ & $12.4 \%$ & 4.26 & 0.993 \\
\hline $\begin{array}{l}\text { The hotel has embraced social media } \\
\text { to handle clients' issues related to RM, } \\
\text { bookings, \& pricings }\end{array}$ & 137 & $2.2 \%$ & $13.9 \%$ & $43.1 \%$ & $32.1 \%$ & $8.8 \%$ & 4.31 & 0.897 \\
\hline $\begin{array}{l}\text { Integration of social media contributes } \\
\text { to performance of your hotel }\end{array}$ & 137 & $4.4 \%$ & $16.8 \%$ & $43.8 \%$ & $26.3 \%$ & $8.8 \%$ & 4.18 & 0.964 \\
\hline Valid N (listwise) & 137 & & & & & & & \\
\hline
\end{tabular}

Source: Authors computation, (2021).

media has been embraced to handle clients' issues related to bookings and reservations $(\mathrm{M}=4.31, \mathrm{SD}=0.897)$. Integration of social media has improved the performance of hotels $(M=4.18, S D=0.964)$. Varini and Sirsi, (2012), proposed novel practices that if hotels can increasingly adopt internet-based procedures 
like virtual networking, survey and reviews, and social networking they are likely to practice RM (Noone et al., 2017).

Table 9 shows findings of revenue management systems. The results revealed that $74.5 \%$ of star-rated hotel facilities have had or interact with RM systems and sub-systems. Some hotels use either one or a combination of two systems. While some use in-house systems, $35 \%$ of others centralized systems $27.4 \%$. About 33.6\% have contracted for RM service from corporate centers in other hotels, while about $45.3 \%$ have outsourced from a third party. Hotels using a combination of several strategies are about $62.8 \%$. Furthermore, most the hotels, $73 \%$ were found to have automated their revenue collection. It was also revealed that 76.5\% have adopted integrated RM soft-wares. Furthermore, their revenue centers are integrated into RM soft-wares adopted. A variety of RMS uses include Amadeus RMS, Delphi, Trust, Elkatra, Ideas, Erbrasoft, Frequency-Opera, and Hotel runner, Ideas. RMS is universally accepted software for RM; it is programmed with strategic information useful to hotel managers (Torc'h, 2015). The software has a high cost to the hotels and requires experts to actualize its working in the hotel facilities, probably, it is for these reason hotels in Kenya have adopted different RMS systems.

Table 10 shows that hotels provide clients with RM information regarding room prices and booking conditions $(\mathrm{M}=4.42, \mathrm{SD}=1.241)$. The hotel provides discount rates in exchange for stricter cancellation $(M=4.30, S D=1.190)$. The hotel insignificant price discounts in exchange for cancellation $(\mathrm{M}=4.39, \mathrm{SD}=$ 0.987). The hotel provides different prices for products perceived by customers as different, e.g., weekend and weekday prices $(\mathrm{M}=4.42, \mathrm{SD}=1.276)$. Changes in booking terms without/informing the customer $(\mathrm{M}=4.47, \mathrm{SD}=1.329)$. Revenue predictions need inputs in an exceeding RM System particularly information about the customers (Morag, 2013). Archival data are important when optimizing occupancy, forecasting booking, and income benefits in hotels (Wang, Yoonjoung Heo, Schwartz, Legohérel, \& Specklin, 2015).

Table 9. RM systems.

\begin{tabular}{cccccc}
\hline & $\mathrm{N}$ & Yes & Percentage & No Percentage \\
\hline Hotel operate a RM system & 137 & 102 & $74.5 \%$ & 35 & $24.5 \%$ \\
RM system is Hotel own in-house & 137 & 48 & $35 \%$ & 89 & $65 \%$ \\
Hotel's RM is Multiple hotels a centralized system & 135 & 37 & $27.4 \%$ & 98 & $72.6 \%$ \\
Hotel has Contracted RM service from Corporate & 137 & 46 & $33.6 \%$ & 91 & $66.4 \%$ \\
The hotel has Outsourced this Function to a third party & 137 & 62 & $45.3 \%$ & 75 & $54.7 \%$ \\
Hotel uses Combination (mixed) of these strategies & 137 & 86 & $62.8 \%$ & 51 & $37.2 \%$ \\
Hotel uses Automation revenue collection & 137 & 100 & $73 \%$ & 37 & $27.0 \%$ \\
Hotel use integrated RM soft-wares. & 137 & 105 & $76.6 \%$ & 32 & $23.4 \%$ \\
Integration of all revenue centres to RM software & 137 & 105 & $76.6 \%$ & 32 & $23.4 \%$ \\
Valid N (listwise) & 133 & & & & \\
\hline
\end{tabular}

Source: Authors computation, (2021). 
Table 10. Revenue management data and information.

\begin{tabular}{|c|c|c|c|c|c|c|c|c|}
\hline \multirow[t]{2}{*}{$\begin{array}{l}\text { RM Data and } \\
\text { Information }\end{array}$} & $\mathbf{N}$ & \multirow[t]{2}{*}{$\begin{array}{l}\text { Very } \\
\text { Rarely }\end{array}$} & \multirow[t]{2}{*}{ Rarely } & \multirow[t]{2}{*}{ Occasionally } & \multirow[t]{2}{*}{ Frequently } & \multirow[t]{2}{*}{$\begin{array}{l}\text { Very } \\
\text { Frequently }\end{array}$} & \multirow{2}{*}{$\begin{array}{c}\text { Mean } \\
\text { Statistic }\end{array}$} & \multirow{2}{*}{$\begin{array}{c}\begin{array}{c}\text { Std. } \\
\text { Deviation }\end{array} \\
\text { Statistic }\end{array}$} \\
\hline & Statistic & & & & & & & \\
\hline $\begin{array}{c}\text { Provision of RM information regarding } \\
\text { prices and booking. }\end{array}$ & 137 & $8.8 \%$ & $13.1 \%$ & $24.1 \%$ & $33.6 \%$ & $20.4 \%$ & 4.42 & 1.241 \\
\hline $\begin{array}{l}\text { Discounts in booking rates in exchange } \\
\text { for stricter cancellation. }\end{array}$ & 137 & $9.5 \%$ & $13.9 \%$ & $25.5 \%$ & $38.0 \%$ & $13.1 \%$ & 4.30 & 1.190 \\
\hline $\begin{array}{l}\text { Hotel insignificant price discounts in } \\
\text { exchange for cancellation }\end{array}$ & 137 & $3.0 \%$ & $4.6 \%$ & $30.7 \%$ & $43.1 \%$ & $8.8 \%$ & 4.39 & 0.987 \\
\hline $\begin{array}{l}\text { There are different prices for products } \\
\text { perceived by customers as different }\end{array}$ & 137 & $10.3 \%$ & $13.9 \%$ & $17.5 \%$ & $38.7 \%$ & $19.5 \%$ & 4.42 & 1.276 \\
\hline $\begin{array}{l}\text { Changes in booking terms without } \\
\text { informing the customer }\end{array}$ & 137 & $9.5 \%$ & $14.6 \%$ & $21.2 \%$ & $27.0 \%$ & $27.7 \%$ & 4.47 & 1.329 \\
\hline Valid N (listwise) & 137 & & & & & & & \\
\hline
\end{tabular}

Source: Authors computation, (2021).

Table 11 on RM Pricing devices, findings reveal that hotels use the following pricing techniques; price discrimination $(\mathrm{M}=4.23, \mathrm{SD}=1.105)$ and hotel erect rate fences $(M=4.31, S D=1.026)$. Dynamic and behavioral pricing $(M=4.20$, $\mathrm{SD}=0.976)$ and lowest price guarantee $(\mathrm{M}=4.39, \mathrm{SD}=1.045)$. $\mathrm{RM}$ pricing tools highlighted here are some of the widely used and have an impression on the prices of the hotel though this depends on price rules, the structure of the hotel, level of the hotel and its presentation (Ivanov \& Zhechev, 2012). Moreover, on Non-pricing devices findings further reveal non-pricing techniques used like capacity management $(\mathrm{M}=4.69, \mathrm{SD}=1.160)$. Management of overbookings ( $\mathrm{M}$ $=4.58, \mathrm{SD}=1.076)$. Length of stay control $(\mathrm{M}=4.39, \mathrm{SD}=0.988)$. Room availability guarantee $(M=4.50, S D=1.023)$. The result confirms the practice of using RM non-pricing tools as highly studied tool (Karaesmen, \& Van-Ryzin, 2004; Koide \& Ishii, 2005; Talluri \& Van Ryzin, 2006).

\subsection{Findings on Financial Performance of Hotels}

Table 12 reveals that the findings of the most commonly used performance indicators in hotels average daily rate $(M=4.28 . S D=1.17)$, occupancy rate at ( $M$ $=4.12 . \mathrm{SD}=1.09)$; revenue per available room $(\mathrm{M}=4.09 . \mathrm{SD}=1.07)$; revenue per occupied room $(\mathrm{M}=4.0 . \mathrm{SD}=1.03$; gross operating profit per available room $(M=4.10 . S D=1.14$; return on investment index $(M=4.26 . S D=1.12)$. The findings further revealed that a large extent the performance indicators are generally used by hotels $(\mathrm{M}=3.83$. $\mathrm{SD}=0.84)$.

Table 13 shows the rate of application of revenue management practices. Respondents feel that $\mathrm{RM}$ affects Average daily rate $(\mathrm{M}=2.39, \mathrm{SD}=0.807)$; improves occupancy rate $(\mathrm{M}=2.42, \mathrm{SD}=0.745)$; REVPAR $(\mathrm{M}=2.42, \mathrm{SD}=0.764)$; REVPOR $(\mathrm{M}=2.40, \mathrm{SD}=0.771)$; GOPPAR $(\mathrm{M}=2.47, \mathrm{SD}=0.767)$; and return on investments $(\mathrm{M}=2.51, \mathrm{SD}=0.698)$. 
Table 11. RM pricing devices.

\begin{tabular}{|c|c|c|c|c|c|c|c|c|}
\hline \multirow[t]{2}{*}{ RM Pricing devices } & $\mathrm{N}$ & \multirow[t]{2}{*}{$\begin{array}{c}\text { Very } \\
\text { Rarely }\end{array}$} & \multirow[t]{2}{*}{ Rarely } & \multirow[t]{2}{*}{ Occasionally } & \multirow[t]{2}{*}{ Frequently } & \multirow[t]{2}{*}{$\begin{array}{c}\text { Very } \\
\text { Frequently }\end{array}$} & \multirow{2}{*}{$\begin{array}{c}\text { Mean } \\
\text { Statistic }\end{array}$} & \multirow{2}{*}{$\begin{array}{c}\begin{array}{c}\text { Std. } \\
\text { Deviation }\end{array} \\
\text { Statistic }\end{array}$} \\
\hline & Statistic & & & & & & & \\
\hline Price discrimination, & 137 & $8.0 \%$ & $15.3 \%$ & $35.0 \%$ & $29.2 \%$ & $12.4 \%$ & 4.23 & 1.105 \\
\hline The erection of rate fences, & 137 & $5.8 \%$ & $13.1 \%$ & $36.5 \%$ & $33.6 \%$ & $10.9 \%$ & 4.31 & 1.026 \\
\hline Dynamic and behavioral pricing, & 137 & $6.6 \%$ & $12.4 \%$ & $43.1 \%$ & $30.7 \%$ & $7.3 \%$ & 4.20 & 0.976 \\
\hline Lowest price guarantee & 137 & $5.1 \%$ & $15.3 \%$ & $27.0 \%$ & $40.9 \%$ & $11.7 \%$ & 4.39 & 1.045 \\
\hline \multicolumn{9}{|l|}{ Non-pricing devices } \\
\hline Capacity management, & 137 & $3.6 \%$ & $12.4 \%$ & $27.7 \%$ & $23.4 \%$ & $32.8 \%$ & 4.69 & 1.160 \\
\hline Overbookings, & 137 & $4.4 \%$ & $10.9 \%$ & $28.5 \%$ & $35.0 \%$ & $21.2 \%$ & 4.58 & 1.076 \\
\hline Length of stay control & 137 & $2.9 \%$ & $13.1 \%$ & $40.1 \%$ & $29.2 \%$ & $14.6 \%$ & 4.39 & .988 \\
\hline Roomavailability guarantee & 137 & $4.4 \%$ & $8.0 \%$ & $39.4 \%$ & $29.9 \%$ & $18.2 \%$ & 4.50 & 1.023 \\
\hline Valid N (listwise) & 137 & & & & & & & \\
\hline
\end{tabular}

Source: Authors computation, (2021).

Table 12. On financial performance of hotels.

\begin{tabular}{|c|c|c|c|c|c|c|c|c|}
\hline & $\mathrm{N}$ & Very & Rarely & Occasionally & Frequently & Very & Mean & $\begin{array}{c}\text { Std. } \\
\text { Deviation }\end{array}$ \\
\hline & Statistic & & & & & & Statistic & Statistic \\
\hline Average daily room rate & 137 & $4.4 \%$ & $19.0 \%$ & $44.5 \%$ & $17.5 \%$ & $13.1 \%$ & 4.28 & 1.168 \\
\hline Occupancy rate & 137 & $5.8 \%$ & $22.6 \%$ & $40.1 \%$ & $19.7 \%$ & $11.7 \%$ & 4.12 & 1.092 \\
\hline Revenue per occupied room (REVPOR) & 137 & $5.8 \%$ & $25.5 \%$ & $40.9 \%$ & $18.2 \%$ & $9.5 \%$ & 4.00 & 1.029 \\
\hline $\begin{array}{l}\text { Gross operating profit per available room } \\
\text { (GOPPAR) }\end{array}$ & 137 & $5.1 \%$ & $29.9 \%$ & $29.9 \%$ & $21.2 \%$ & $14.6 \%$ & 4.10 & 1.139 \\
\hline Return on Investments & 137 & $3.7 \%$ & $27 \%$ & $29.2 \%$ & $18.2 \%$ & $21.9 \%$ & 4.26 & 1.220 \\
\hline Valid N (listwise) & 137 & & & & & & & \\
\hline
\end{tabular}

Source: Authors computation, (2021).

Table 13. Rate of application of RM practices.

\begin{tabular}{|c|c|c|c|c|c|c|}
\hline & $\mathbf{N}$ & Lowly & Moderately & Highly & Mean & $\begin{array}{c}\text { Std. } \\
\text { Deviation }\end{array}$ \\
\hline & Statistic & & & & Statistic & Statistic \\
\hline Rate how application of RM improves Average daily room rate & 137 & $20.4 \%$ & $20.4 \%$ & $59.1 \%$ & 2.39 & 0.807 \\
\hline Rate how application of RM improves Occupancy rate & 137 & $15.3 \%$ & $27.0 \%$ & $57.7 \%$ & 2.42 & 0.745 \\
\hline $\begin{array}{l}\text { Rate how application of RM improves Revenue per available room } \\
\text { (REVPAR) }\end{array}$ & 137 & $16.8 \%$ & $24.1 \%$ & $59.1 \%$ & 2.42 & 0.764 \\
\hline
\end{tabular}




\section{Continued}

Rate how application of RM improves Revenue per occupied room (REVPOR)

Rate how application of RM improves Gross operating profit per available room (GOPPAR)

Rate how application of RM improves Return on Investments Valid N (listwise)

$\begin{array}{llllll}137 & 17.5 \% & 24.8 \% & 57.7 \% & 2.40 & 0.771 \\ 137 & 16.8 \% & 19.7 \% & 63.5 \% & 2.47 & 0.767 \\ 137 & 11.7 \% & 25.5 \% & 62.8 \% & 2.51 & 0.698 \\ 137 & & & & & \end{array}$

Source: Authors computation, (2021).
The findings presented by Table 14 shows that application of RM tools and procedures contributes positively to the revenues of hotels $(\mathrm{M}=3.47, \mathrm{SD}=$ 1.35); Revenues attributable to revenue management applications exceed the costs attributable to revenue management applications $(\mathrm{M}=3.28, \mathrm{SD}=1.26)$; that hotels are monitoring and adopting recent applications and Technologies for revenue management $(\mathrm{M}=3.25, \mathrm{SD}=1.16)$; Revenue management contributes towards gaining and improvement of competitive advantage $(\mathrm{M}=3.26$, $\mathrm{SD}$ $=1.20)$; Revenue management contributes towards developing efficient competition strategies $(\mathrm{M}=3.27, \mathrm{SD}=1.17)$; Revenue management assists in decreasing idle capacity $(\mathrm{M}=3.37, \mathrm{SD}=1.27)$; Revenue management applications increases our total revenue $(\mathrm{M}=3.56, \mathrm{SD}=1.25)$.

On average on the use of performance of indicators $(\mathrm{M}=4.0669, \mathrm{SD}=0.881)$, on application of $\mathrm{RM}(\mathrm{M}=2.4355, \mathrm{SD}=0.671)$, application of $\mathrm{RM}$ on financial performance $(\mathrm{M}=3.3525, \mathrm{SD}=1.05435)$. About $35 \%$ of the respondents reported that $\mathrm{Rm}$ has increased their revenues by less than $5 \%$, while, $24.8 \%$ said that revenues had increased with average $(6 \%-10 \%)$. About $19 \%$ said that their revenues had increased by $(11 \%-20 \%)$; while $11.7 \%$ registered increment by of $(21 \%-30 \%) ; 9.5 \%$ revealed that their revenues had increased by over $30 \%$. The findings supported by (Karmarkar \& Dutta, 2011) who argued that when appropriately implemented, revenue management results in 33\% higher revenues than traditional restaurants' traditional methods.

\section{Testing the Correlations}

To establish whether there is a linkage between internal and external determinants, revenue management practices and financial performance. Three relationships were tested. The direct relationships between independent and dependent variable, then, the indirect relationship between independent variable as mediator, and the relationship between the mediator and the dependent variable. The direct relationship this is the relationship between internal and external determinants and financial performance of hotels. The tests of the regression analysis in Table 15 revealed that there is a link between internal and external hotel determinants and financial performance $(\mathrm{R}=0.457$, Sig. $<0.05)$ indicating that $45.7 \%$ of the variability of financial performance is explained by the internal and external hotel determinants. The findings support (Sainaghi, 2011) whose 
Table 14. On application RM tools and procedures and hotel performance.

\begin{tabular}{|c|c|c|c|c|c|c|c|c|}
\hline & $\mathbf{N}$ & Strongly & Disagree & Average & Agree & Strongly & Mean & $\begin{array}{c}\text { Std. } \\
\text { Deviation }\end{array}$ \\
\hline & Statistic & & & & & & Statistic & Statistic \\
\hline $\begin{array}{l}\text { In general the application of RM tools and procedures } \\
\text { contributes positively to the revenues of our hotel. }\end{array}$ & 137 & $8.0 \%$ & $19.7 \%$ & $23.4 \%$ & $14.6 \%$ & $34.3 \%$ & 3.47 & 1.351 \\
\hline $\begin{array}{l}\text { Revenues attributable to RM applications exceed the } \\
\text { costs attributable to revenue management applications }\end{array}$ & 137 & $8.0 \%$ & $22.6 \%$ & $24.8 \%$ & $22.6 \%$ & $21.9 \%$ & 3.28 & 1.259 \\
\hline $\begin{array}{l}\text { We are monitoring and adopting recent applications } \\
\text { and Technologies for revenue management }\end{array}$ & 137 & $4.4 \%$ & $25.5 \%$ & $29.9 \%$ & $21.2 \%$ & $19.0 \%$ & 3.25 & 1.162 \\
\hline $\begin{array}{l}\text { RM contributes towards gaining and improvement } \\
\text { of competitive advantage }\end{array}$ & 137 & $6.6 \%$ & $24.8 \%$ & $21.2 \%$ & $30.7 \%$ & $16.8 \%$ & 3.26 & 1.196 \\
\hline $\begin{array}{l}\text { RM contributes towards developing efficient } \\
\text { competition strategies }\end{array}$ & 137 & $4.4 \%$ & $25.5 \%$ & $27.7 \%$ & $23.4 \%$ & $19.0 \%$ & 3.27 & 1.166 \\
\hline RM assists in decreasing idle capacity & 137 & $5.8 \%$ & $24.8 \%$ & $21.9 \%$ & $21.2 \%$ & $26.3 \%$ & 3.37 & 1.272 \\
\hline RM applications increases our total revenue & 137 & $5.1 \%$ & $17.5 \%$ & $25.5 \%$ & $19.7 \%$ & $32.1 \%$ & 3.56 & 1.248 \\
\hline Valid N (listwise) & 137 & & & & & & & \\
\hline
\end{tabular}

Source: Authors computation, (2021).

Table 15. Model of the correlation between internal and external determinants and financial performance of hotels.

\begin{tabular}{|c|c|c|c|c|c|c|}
\hline Model & $\mathrm{R}$ & R Square & Adjusted R Square & \multicolumn{3}{|c|}{ Std. Error of the Estimate } \\
\hline \multirow[t]{5}{*}{1} & $0.457^{\mathrm{a}}$ & 0.209 & 0.203 & 2.84419 & & \\
\hline & \multicolumn{6}{|c|}{ Coefficients $^{\mathrm{a}}$} \\
\hline & \multirow{2}{*}{ Model } & \multicolumn{2}{|c|}{ Unstandardized Coefficients } & Standardized Coefficients & \multirow{2}{*}{$\mathrm{T}$} & \multirow{2}{*}{ Sig. } \\
\hline & & B & Std. Error & Beta & & \\
\hline & (Constant) & 1.863 & 1.752 & & 1.063 & 0.289 \\
\hline 1 & $\begin{array}{l}\text { Internal and } \\
\text { external } \\
\text { determinants }\end{array}$ & 0.521 & 0.087 & 0.457 & 5.966 & 0.000 \\
\hline
\end{tabular}

${ }^{\mathrm{a} D e p e n d e n t ~ v a r i a b l e: ~ F i n a n c i a l ~ p e r f o r m a n c e ~ o f ~ h o t e l s . ~ S o u r c e: ~ A u t h o r s ~ c o m p u t a t i o n, ~(2021) . ~}$

findings revealed that star rating features a significant association with RevPAR and further suggested that the hotel facility's central location enlarges its RevPAR approximation worth.

The indirect relationship was tested; the first step was to test the relationship between internal and external hotel determinants and Revenue management practices (a). The findings in Table 16 revealed that there is a link between internal and external hotel determinants and revenue management practices. The $(\mathrm{R}=0.478$, Sig. $<0.05)$. Meaning that $47.8 \%$ variability of $\mathrm{RM}$ practices can be explained by internal and external determinants. The findings supports that the rate of environment uncertainty significantly affects the hotel's performance 
(Awang et al., 2008).

The second step for testing indirect relationship was to test relationship between Revenue management practices and financial performance of hotels (b) and the findings as reflected in Table 17 revealed that there was a linkage $(R=$ 0.751 sig. $<0.05)$.this means that $75.1 \%$ variability of financial performance of hotels is explained by RM practices. The findings supports (Ortega, 2016) whose findings reveal that RM systems from a databank of rated chain hotels are efficient in enhancing occupancy than realizing more significant charges. Also, Guadix et al., (2010) study revealed that each further advancement in technology management leads to more sophisticated revenue business capabilities and the results included performance indexes such as occupancy rate, efficiency rate, and yield.

The Mediation role of RM practices on the relationship between internal and external hotel determinants and financial performance of hotels. The findings presented in Table 18 revealed that RM practices mediates the relationship between internal and external determinants and financial performance $(R=0.759$, sig. < 0.05).the beta value for internal and external hotel determinants that was 0.457 (in the direct relationship) has reduced to 0.127 after introducing RM

Table 16. On model summary of the relationship between internal and external determinants and RM practices.

\begin{tabular}{|c|c|c|c|c|c|c|}
\hline Model & $\mathrm{R}$ & R Square & Adjusted R Square & \multicolumn{3}{|c|}{ Std. Error of the Estimate } \\
\hline \multirow[t]{5}{*}{1} & $0.478^{\mathrm{a}}$ & 0.228 & 0.223 & \multicolumn{3}{|l|}{4.22064} \\
\hline & \multicolumn{6}{|c|}{ Coefficients $^{\mathrm{a}}$} \\
\hline & \multirow{2}{*}{ Model } & \multicolumn{2}{|c|}{ Unstandardized Coefficients } & Standardized Coefficients & \multirow{2}{*}{$\mathrm{t}$} & \multirow{2}{*}{ Sig. } \\
\hline & & $\mathrm{B}$ & Std. Error & Beta & & \\
\hline & (Constant) & 20.062 & 2.599 & & 7.718 & 0.000 \\
\hline 1 & $\begin{array}{l}\text { Internal and } \\
\text { external hotel } \\
\text { determinants }\end{array}$ & 0.818 & 0.129 & 0.478 & 6.320 & 0.000 \\
\hline
\end{tabular}

${ }^{a}$ Dependent variable: RM practices. Source: Authors computation, (2021).

Table 17. Model summary of the correlation between RM practices and financial performance of hotels.

\begin{tabular}{|c|c|c|c|c|c|c|}
\hline Model & $\mathrm{R}$ & R Square & Adjusted R Square & \multicolumn{3}{|c|}{ Std. Error of the Estimate } \\
\hline 1 & $0.751^{\mathrm{a}}$ & 0.564 & 0.561 & 2.11085 & & \\
\hline \multicolumn{7}{|c|}{ Coefficients $^{\mathrm{a}}$} \\
\hline & \multirow{2}{*}{ Model } & \multicolumn{2}{|c|}{ Unstandardized Coefficients } & \multirow{2}{*}{$\begin{array}{c}\text { Standardized Coefficients } \\
\text { Beta }\end{array}$} & \multirow{2}{*}{$\mathrm{T}$} & \multirow{2}{*}{ Sig. } \\
\hline & & B & Std. Error & & & \\
\hline \multirow{2}{*}{1} & (Constant) & -5.946 & 1.386 & & -4.292 & 0.000 \\
\hline & $\mathrm{RM}$ practices & 0.500 & 0.038 & 0.751 & 13.218 & 0.000 \\
\hline
\end{tabular}

${ }^{a}$ Dependent variable: Financial performance. Source: Authors computation, (2021). 
Table 18. Model summary of mediation of RM practices on relationship between determinants and hotel financial performance.

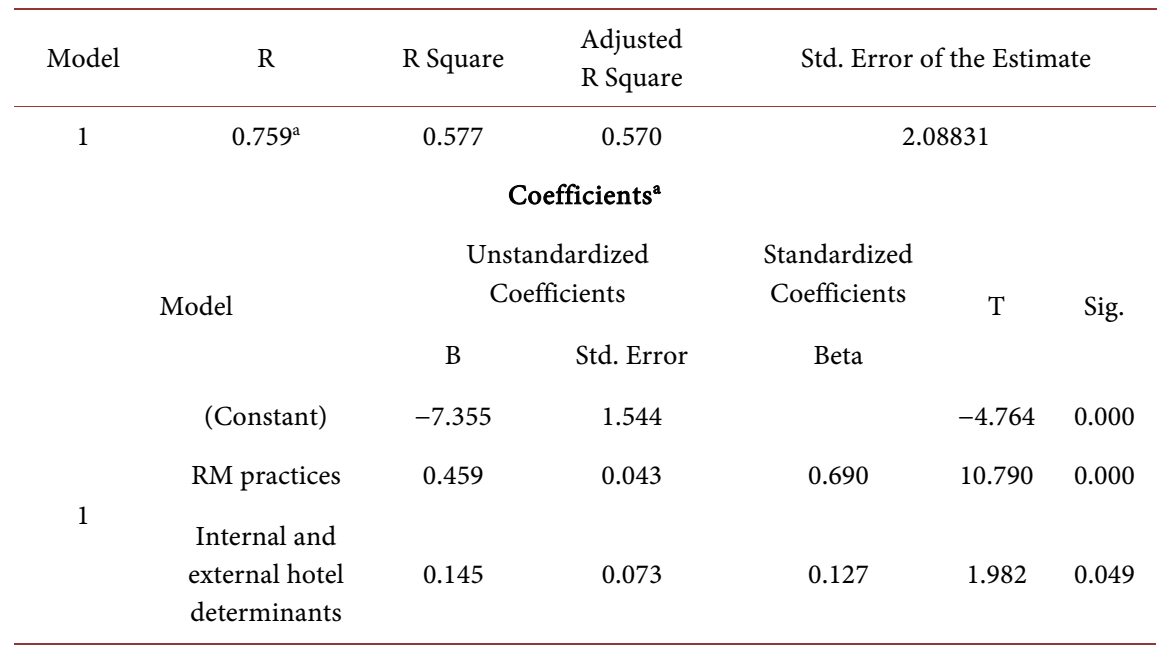

${ }^{a}$ Dependent variable: Financial performance of hotels. Source: Authors computation, (2021).

practices as a vector mediator. Which shows that there is actually partial mediation, meaning that revenue management practices partially mediates the relationship between internal and external determinants and financial performance of hotels. The finding supports the hypothesis by (Murimi et al, 2021) who hypothesis that there is a relationship between those variables.

\section{Limitations}

This study was conducted under extra ordinary circumstances when the hotel industry in is experiencing low downturns because of restrictions imposed by government of Kenya over Covid 19 Pandemic especially the lock down of the country of the country during data collection period. The researcher had envisaged to do a researcher administered questionnaire but most respondents opted for self-administered, and others insisted on use of online survey. While this made it easier to collect data from hotels in remote areas, it posed challenges of delayed Reponses and incomplete questionnaires and it is for this reason that the study response rate was not $100 \%$. The future research may consider adopting other methods of data collections like in-depth interviews to supplement quantitative data.

\section{Conclusion}

Revenue management is a very necessary tool in the modern hotel industry and should be given a chance. Hotels should adopt RM practices and Hotels should automate RM to advance efficiency in hotels because they induce a $37.0 \%$ change (Kimes, 2010). The findings of the study have established a link between internal and external determinants of revenue management and revenue management practices, as well as their impacts on performance of hotels. The findings have empirically supported the hypothesized relationship developed in the theoretical 
framework by (Murimi et al., 2021) and have revealed that RM practices mediate the relationship between internal and external determinants and financial performance of hotels in Kenya. This finding proposes that the hotels may adopt RM practices to enhance their financial performance as they address the challenges brought about by internal and external factors. The research adds to the body of empirical evidence for revenue management and financial performance conceptualization and description. The findings can aid in the conceptualization and advancement of future studies on hotel revenue management.

\section{Acknowledgements}

The authors would like to thank all the respondents from classified hotels in Kenya for sharing their information during the survey and acknowledge the support by Higher Education Loans Board Scholarship Fund.

\section{Conflicts of Interest}

The authors declare no conflicts of interest regarding the publication of this paper.

\section{References}

Abad, P., De la Fuente-Cabrero, C., González-Serrano, L., \& Talón-Ballestero, P. (2019). Determinants of Successful Revenue Management. Tourism Review, 74, 666-678. https://doi.org/10.1108/TR-07-2018-0091

Adedipe, A. (2018). Star Rating Attributes and Accommodation Performance of Upmarket Hotels in Abuja Territory, Nigeria. Doctoral Dissertation, Nairobi: Kenyatta University.

Anastassopoulos, G., Filippaios, F., \& Phillips, P. (2009). An Eclectic Investigation of Tourism Multinationals: Evidence from Greece. International Journal of Hospitality Management, 28, 185-194. https://doi.org/10.1016/j.ijhm.2008.06.014

Anderson, C. K., \& Xie, X. (2010). Improving Hospitality Industry Sales: Twenty-Five Years of Revenue Management. Cornell Hospitality Quarterly, 51, 53-67.

https://doi.org/10.1177/1938965509354697

Anuwichanont, J. (2011). The Impact of Price Perception on Customer Loyalty in the Airline Context. Journal of Business \& Economics Research (JBER), 9, 37-50. https://doi.org/10.19030/jber.v9i9.5646

Awang, K. W., Ishak, N. K., Radzi, S. M., \& Taha, A. Z. (2008). Environmental Variables and Performance: Evidence from the Hotel Industry in Malaysia. International Journal of Economics and Management, 2, 59-79.

Azadegan, A., Patel, P. C., Zangoueinezhad, A., \& Linderman, K. (2013). The Effect of Environmental Complexity and Environmental Dynamism on Lean Practices. Journal of Operations Management, 31, 193-212. https://doi.org/10.19030/jber.v9i9.5646

Baldigara, T., \& Koic, M. (2015). Modelling Occupancy Rates in Croatian Hotel Industry. International Journal of Business Administration, 6, 121. https://doi.org/10.5430/ijba.v6n3p121

Baum, J. A., \& Mezias, S. J. (1992). Localized Competition and Organizational Failure in the Manhattan Hotel Industry, 1898-1990. Administrative Science Quarterly, 37, 580-604. 


\section{https://doi.org/10.2307/2393473}

Bertsimas, D., \& Popescu, I. (2003). Revenue Management in a Dynamic Network Environment. Transportation Science, 37, 257-277. https://doi.org/10.2307/2393473

Butler, B. S. (2001). Membership Size, Communication Activity, and Sustainability: A Resource-Based Model of Online Social Structures. Information Systems Research, 12, 346-362. https://doi.org/10.1287/isre.12.4.346.9703

Carvell, S. A., \& Quan, D. A. (2008). Exotic Reservations-Low Price Guarantee. International Journal of Hospitality Management, 27, 162-169.

https://doi.org/10.1016/j.ijhm.2007.07.016

Cetin, G., Demirciftci, T., \& Bilgihan, A. (2016). Meeting Revenue Management Challenges: Knowledge, Skills and Abilities. International Journal of Hospitality Management, 57, 132-142. https://doi.org/10.1016/j.ijhm.2016.06.008

Chiutsi, S., \& Mudzengi, B. K. (2017). Tourism Seasonality and Destination Management Implications for Mana Pools Tourist Destination in Zimbabwe. African Journal of Hospitality, Tourism and Leisure, 6, 1-13.

Choi, S., \& Kimes, S. E. (2002). Electronic Distribution Channels' Effect on Hotel Revenue Management. The Cornell Hotel and Restaurant Administration Quarterly, 43, 23-31. https://doi.org/10.1177/0010880402433002

Chung, J. Y. (2009). Seasonality in Tourism: A Review. E-Review of Tourism Research, 7, 73.

Cross, R. G., Higbie, J. A., \& Cross, Z. N. (2011). Milestones in the Application of Analytical Pricing and Revenue Management. Journal of Revenue and Pricing Management, 10, 8-18. https://doi.org/10.1057/rpm.2010.39

Cytonn Real Estate (2017). Nairobi’s Hospitality Sector Report. Nairobi. https://www.cytonn.com/uploads/downloads/hospitality-report-vf.pdf

Demirciftci, T., Cobanoglu, C., Beldona, S., \& Cummings, P. (2010). Room Rate Parity Analysis across Different Hotel Distribution Channels in the U.S. Journal of Hospitality Marketing \& Management, 19, 295-308. https://doi.org/10.1080/19368621003667010

El Gayar, N. F., Saleh, M., Atiya, A., El-Shishiny, H., Zakhary, A. A. Y. F., \& Habib, H. A. A. M. (2011). An Integrated Framework for Advanced Hotel Revenue Management. International Journal of Contemporary Hospitality Management, 23, 84-98.

Enz, C. A., Verma, R., Walsh, K., Kimes, S. E., \& Siguaw, J. D. (2010). Cases in Innovative Practices in Hospitality and Related Services: Set 3.

Erdem, M., \& Jiang, L. (2016). An Overview of Hotel Revenue Management Research and Emerging Key Patterns in the Third Millennium. Journal of Hospitality and Tourism Technology, 7, 300-331. https://doi.org/10.1108/JHTT-10-2014-0058

Ferguson, M., \& Smith, S. (2014). The Changing Landscape of Hotel Revenue Management and the Role of the Hotel Revenue Manager. Journal of Revenue and Pricing Management, 13, 224-232. https://doi.org/10.1057/rpm.2014.11

Gallego, G., \& Van Ryzin, G. (1997). A Multiproduct Dynamic Pricing Problem and Its Applications to Network Yield Management. Operations Research, 45, 24-41. https://doi.org/10.1287/opre.45.1.24

Guadix, J., Cortés, P., Onieva, L., \& Muñuzuri, J. (2010). Technology Revenue Management System for Customer Groups in Hotels. Journal of Business Research, 63, 519-527. https://doi.org/10.1016/j.jbusres.2009.04.013

Haensel, A., \& Koole, G. (2011). Booking Horizon Forecasting with Dynamic Updating: A Case Study of Hotel Reservation Data. International Journal of Forecasting, 27, 942- 
960. https://doi.org/10.1016/j.ijforecast.2010.10.004

Hernandez, N. (2015). Restaurant Revenue Management: Examining Reservation Policy Implications at Fine Dining Restaurants.

Hospitality Professionals Association (2013). Revenue Management: An Introduction to Practitioners. Bournemouth: Hospitality Professionals Association, Wentworth Jones Limited.

Ivanov, S., \& Zhechev, V. (2012). Hotel Revenue Management-A Critical Literature Review. Tourism: An International Interdisciplinary Journal, 60, 175-197.

Jeffrey, D., \& Barden, R. R. D. (2000a). An Analysis of Daily Occupancy Performance: A Basis for Effective Hotel Marketing? International Journal of Contemporary Hospitality Management, 12, 179-189. https://doi.org/10.1108/09596110010320715

Jeffrey, D., \& Barden, R. R. D. (2000b). Monitoring Hotel Performance Using Occupancy Time-Series Analysis: The Concept of Occupancy Performance Space. International Journal of Tourism Research, 2, 383-402. https://doi.org/10.1002/1522-1970(200011/12)2:6<383::AID-JTR237>3.0.CO;2-4

Karaesmen, I., \& Van Ryzin, G. (2004). Overbooking with Substitutable Inventory Classes. Operations Research, 52, 83-104. https://doi.org/10.1287/opre.1030.0079

Karmarkar, S., \& Dutta, G. (2011). Optimal Table-Mix and Acceptance? Rejection Problems in Restaurants. International Journal of Revenue Management, 5, 1-15. https://doi.org/10.1504/IJRM.2011.038616

Kenya National Bureau of Statistics (KNBS) (2020). Economic Survey 2020. Nairobi. https://s3-eu-west-1.amazonaws.com/s3.sourceafrica.net/documents/119905/KNBS-Ec onomic-Survey-2020.pdf

Kimes, S. E. (2003). Revenue Management: A Retrospective. Cornell Hotel and Restaurant Administration Quarterly, 44, 131-138. https://doi.org/10.1177/001088040304400518

Kimes, S. E. (2010). Strategic Pricing through Revenue Management. https://ecommons.cornell.edu/bitstream/handle/1813/72344/Kimes72 Strategic Pricin g_Through Revenue Management.pdf?sequence $=1$ \&isAllowed $=y$

Koide, T., \& Ishii, H. (2005). The Hotel Yield Management with Two Types of Room Prices, Overbooking and Cancellations. International Journal of Production Economics, 93, 417-428. https://doi.org/10.1016/j.ijpe.2004.06.038

Koushik, D., Higbie, J. A., \& Eister, C. (2012). Retail Price Optimization at Intercontinental Hotels Group. Interfaces, 42, 45-57. https://doi.org/10.1287/inte.1110.0620

Le Torc'h, M. (2013). Revenue Management and It Impacts on Its Actors in the Hospitality Industry. Doctoral Dissertation.

Lee, C., Bergin-Seers, S., Galloway, G., O’Mahony, B., \& McMurray, A. (2008). Seasonality in the Tourism Industry. Impacts and Strategies. Gold Coast: CRC for Sustainable Tourism Pty Ltd.

Li, D. Y., \& Liu, J. (2014). Dynamic Capabilities, Environmental Dynamism, and Competitive Advantage: Evidence from China. Journal of Business Research, 67, 2793-2799. https://doi.org/10.1016/j.jbusres.2012.08.007

Liu, P. (2012). Optimizing Hotel Pricing: A New Approach to Hotel Reservations.

López-Ruiz, D., Baeza-Gazca, E., Cantú-Flores, K., Webber-Garza, P., Arrambide-Leal, E., Ruiz-Cantisani, M., \& Cárdenas-Barrón, L. (2019). Diagnosis of Information Systems for the Hotel Sector at Puerto-Morelos (pp. 1469-1474). IIE Annual Conference Proceedings. 
Luo, J. M., \& Lam, C. F. (2017). Urbanization Effects on Hotel Performance: A Case Study in China. Cogent Business \& Management, 4, Article ID: 1412873. https://doi.org/10.1080/23311975.2017.1412873

Mašić, S. I. (2013). The Performance of the Serbian Hotel Industry/Performanse Hotelskog Poslovanja U Srbiji. The European Journal of Applied Economics, 10, 24-31. https://doi.org/10.2478/sjas10-4481

Miricho, M. N. (2013). Yield Management Strategy in Kenya's Town Hotels: Opportunities and Scope in Room-Stock Management. Doctoral Dissertation, Nairobi: Kenyatta University.

Mohd, W., Idris, S., \& Momani, R. A. (2013). Impact of Environmental Dynamism on Marketing Strategy Comprehensiveness and Organizational Performance. International Journal of Business and Management, 8,40 . https://doi.org/10.5539/ijbm.v8n9p40

Morag, C. J. (2013). Effective Revenue Management in the Hospitality Industry. London: EyeforTravel Ltd.

Murimi, M., \& Wadongo, B. (2021). Application of Revenue Management Practices in Star-Rated Hotels in Kenya. African Journal of Hospitality, Tourism and Leisure, 10, 559-574. https://doi.org/10.46222/ajhtl.19770720-118

Murimi, M., Wadongo, B., \& Olielo, T. (2021). Determinants of Revenue Management Practices and Their Impacts on the Financial Performance of Hotels in Kenya: A Proposed Theoretical Framework. Future Business Journal, 7, 1-7. https://doi.org/10.1186/s43093-020-00050-9

Njoroge, J. K., Ongeti, W. J., Kinuu, D., \& Kasomi, F. M. (2016). Does External Environment Influence Organizational Performance? The Case of Kenyan State Corporations. Management and Organizational Studies, 3, 41-51. https://doi.org/10.5430/mos.v3n3p41

Noh, S., Lee, H. C., \& Lee, S. K. (2016). Exploring the Determinants of Strategic Revenue Management with Idiosyncratic Room Rate Variations.

Noone, B. M., \& Mattila, A. S. (2009). Hotel Revenue Management and the Internet: The Effect of Price Presentation Strategies on Customers' Willingness to Book. International Journal of Hospitality Management, 28, 272-279. https://doi.org/10.1016/j.ijhm.2008.09.004

Noone, B. M., Enz, C. A., \& Glassmire, J. (2017). Total Hotel Revenue Management: A Strategic Profit Perspective.

Noone, B. M., McGuire, K. A., \& Rohlfs, K. V. (2011). Social Media Meets Hotel Revenue Management: Opportunities, Issues and Unanswered Questions. Journal of Revenue and Pricing Management, 10, 293-305. https://doi.org/10.1057/rpm.2011.12

O’Neill, J. W. (2011). Hotel Occupancy: Is the Three-Year Stabilization Assumption Justified? Cornell Hospitality Quarterly, 52, 176-180. https://doi.org/10.1177/1938965510393733

Oaten, S., Le Quesne, K., \& Segal, H. (2015). Adapting to Uncertainty-The Global Hotel Industry. Travel and Tourism Competitiveness Report.

Odawa, E. L. (2017). The Efficacy of Information and Communication Technology in Creating Competitive Advantage in 3-5 Star-Rated Hotels in Nairobi, Kenya. Doctoral Dissertation, Nairobi: Kenyatta University.

Oliveri-Martínez-Pardo, G. (2017). Principles of Revenue Management and Their Applications.

Olsen, M. D., Tse, E. C., \& West, J. J. (1992). Environmental Scanning Analysis Form. 
Strategic Management in the Hospitality Industry.

Ortega, B. (2016). Revenue Management Systems and Hotel Performance in the Economic Downturn. International Journal of Contemporary Hospitality Management, 28 , 658-680. https://doi.org/10.1108/IJCHM-07-2014-0324

Padhi, S. S., \& Aggarwal, V. (2011). Competitive Revenue Management for Fixing Quota and Price of Hotel Commodities under Uncertainty. International Journal of Hospitality Management, 30, 725-734. https://doi.org/10.1016/j.ijhm.2010.12.007

Palmer, A., \& Mc-Mahon-Beattie, U. (2008). Variable Pricing through Revenue Management: A Critical Evaluation of Affective Outcomes. Management Research News, 31, 189-199. https://doi.org/10.1108/01409170810851285

Patel, V. (2020). Top Hotel Revenue Management Strategies to Adopt in 2020. https://www.ezeeabsolute.com https://www.ezeeabsolute.com/blog/hotel-revenue-management-strategies

Pawlicz, A., \& Napierala, T. (2017). The Determinants of Hotel Room Rates: An Analysis of the Hotel Industry in Warsaw, Poland. International Journal of Contemporary Hos pitality Management, 29, 571-588. https://doi.org/10.1108/IJCHM-12-2015-0694

Pekgün, P., Menich, R. P., Acharya, S., Finch, P. G., Deschamps, F., Mallery, K., \& Fuller, J. (2013). Carlson Rezidor Hotel Group Maximizes Revenue through Improved Demand Management and Price Optimization. Interfaces, 43, 21-36. https://doi.org/10.1287/inte.1120.0660

Sainaghi, R. (2011). RevPAR Determinants of Individual Hotels: Evidences from Milan. International Journal of Contemporary Hospitality Management, 23, 297-311. https://doi.org/10.1108/09596111111122497

Santoro, G. (2015). Evaluating Performance in the Hotel Industry: An Empirical Analysis of Piedmont. Journal of Investment and Management, 4, 17-22. https://doi.org/10.11648/j.jim.s.2015040101.13

Shrestha, A., \& Fissha, H. (2017). Impact of Airbnb on Hotel Industry in Helsinki.

Talluri, K. T., \& Van Ryzin, G. J. (2006). The Theory and Practice of Revenue Management (Vol. 68). Berlin: Springer Science \& Business Media.

Tang, C. M. F. (2011). Hotel Occupancy Rate Volatility and Its Determinants. Doctoral Dissertation, Melbourne: Victoria University.

Torc'h, L. (2015). Revenue Management and It Impacts on Its Actors in the Hospitality Industry.

Tourism Regulatory Authority (TRA) (2020). Classification of Hotels in Kenya. https://www.tourismauthority.go.ke/index.php/quality-assuarance/classification-criteria

TRA Tourism Regulatory Authority (2020). Classification of Hotels in Kenya. https://www.tourismauthority.go.ke/index.php/quality-assuarance/classification-criteria

Tranter, K. A., Stuart-Hill, T., \& Parker, J. (2008). Introduction to Revenue Management for the Hospitality Industry. Harlow: Pearson Prentice Hall.

Varini, K., \& Sirsi, P. (2012). Social Media and Revenue Management; Where Should the Two Meet? Journal of Technology Management for Growing Economies, 3, 33-46. https://doi.org/10.15415/jtmge.2012.31002

Wang, C. L., Senaratne, C., \& Rafiq, M. (2015). Success Traps, Dynamic Capabilities and Firm Performance. British Journal of Management, 26, 26-44. https://doi.org/10.1111/1467-8551.12066

Wang, X. L., Yoonjoung Heo, C., Schwartz, Z., Legohérel, P., \& Specklin, F. (2015). Revenue Management: Progress, Challenges, and Research Prospects. Journal of Travel \& 
Tourism Marketing, 32, 797-811. https://doi.org/10.1080/10548408.2015.1063798

Wang, X. W., Tian, X., Li, K., \& Hu, Z. J. (2013). Research on Factors Influencing Hotel Revenue Management Decision-Making and Performance: An Empirical Study Based on High Star-Rated Hotels in China. Tourism Tribune, 28, 25-33.

Weatherford, L. R. (1995). Length of Stay Heuristics: Do They Really Make a Difference? The Cornell Hotel and Restaurant Administration Quarterly, 36, 70-79. https://doi.org/10.1177/001088049503600620

Whitfield, R. I., \& Duffy, A. H. B. (2013). Extended Revenue Forecasting within a Service Industry. International Journal of Production Economics, 141, 505-518.

https://doi.org/10.1016/j.ijpe.2011.11.015

Wijbenga, F. H., \& Van Witteloostuijn, A. (2007). Entrepreneurial Locus of Control and Competitive Strategies-The Moderating Effect of Environmental Dynamism. Journal of Economic Psychology, 28, 566-589. https://doi.org/10.1016/j.joep.2007.04.003

Zhang, D., \& Weatherford, L. (2017). Dynamic Pricing for Network Revenue Management: A New Approach and Application in the Hotel Industry. INFORMS Journal on Computing, 29, 18-35. https://doi.org/10.1287/ijoc.2016.0713

Zhang, M., \& Bell, P. C. (2010). Fencing in the Context of Revenue Management. International Journal of Revenue Management, 4, 42-68.

https://doi.org/10.1504/IJRM.2010.030030

Zheng, C., \& Forgacs, G. (2017). The Emerging Trend of Hotel Total Revenue Management. Journal of Revenue and Pricing Management, 16, 238-245.

https://doi.org/10.1057/s41272-016-0057-x 